\title{
Isotopic Tracking of Hanford 300 Area Derived Uranium in the Columbia River
}

\author{
John N. Christensen ${ }^{1}$, P. Evan Dresel ${ }^{2 a}$, Mark E. Conrad ${ }^{1}$, Gregory W. Patton ${ }^{2}$, and \\ Donald J. DePaolo ${ }^{1,3}$ \\ 1. Lawrence Berkeley National Laboratory, 1 Cyclotron Rd., Berkeley, CA 94720 \\ 2. Pacific Northwest National Laboratory, MS K6-96, Richland, WA 99352 \\ 3. University of California Berkeley, Berkeley, CA 94720 \\ *Corresponding author, phone: 510-486-6735, FAX 510-486-5496 \\ e-mail: jnchristensen@lbl.gov
}

\begin{abstract}
Our objectives in this study are to quantify the discharge rate of uranium (U) to the Columbia River from the Hanford Site's 300 Area, and to follow that U down river to constrain its fate. Uranium from the Hanford Site has variable isotopic composition due to nuclear industrial processes carried out at the site. This characteristic makes it possible to use high-precision isotopic measurements of $U$ in environmental samples to identify even trace levels of contaminant $U$, determine its sources, and estimate discharge rates. Our data on river water samples indicate that as much as 3.2 $\mathrm{kg}$ /day can enter the Columbia River from the 300 Area, which is only a small fraction of the total load of dissolved natural background $U$ carried by the Columbia River. This very low-level of Hanford derived $U$ can be discerned, despite dilution to $<1 \%$ of natural background U, $400 \mathrm{~km}$ downstream from the Hanford Site. These results indicate that isotopic methods can allow the amounts of $U$ from the 300 Area of the Hanford Site entering the Columbia River to be measured accurately to ascertain whether they are an environmental concern, or are insignificant relative to natural uranium background in the Columbia River.
\end{abstract}

\section{Introduction}

The Columbia River, with a drainage area of $7.24 \times 10^{3} \mathrm{~km}^{2}$ (US and Canada), has the greatest discharge volume of any river west of the continental divide and of any river draining into the eastern Pacific Ocean (1). It represents an important resource to the Pacific Northwest, including spawning grounds for Pacific salmon, sources of municipal and irrigation water, and as a major source of hydroelectric power representing in aggregate the largest system in the US. The Hanford Site, south central Washington, is located on the Columbia River and was selected in December 1942 as the site for Pu production for the Manhattan Project, in large part due to the ready availability of power

\footnotetext{
${ }^{a}$ Current address: Victoria State Department of Primary Industries, PO Box 3100, Bendigo Delivery Centre, Bendigo, Victoria 3554, Australia
} 
from the newly operational Grand Coulee Dam, and abundant water for nuclear reactor cooling and fuel processing (2). From the WWII-era through the end of Pu production in 1987, over 100,000 metric tons of uranium were processed through the nuclear reactors and chemical Pu separation processes (3). The Hanford reach of the Columbia River is the only unimpounded section in the U.S. of the Columbia River (above Bonneville Dam) and is an important spawning habitat for fall Chinook salmon (Oncorhynchus tshawytscha $)(4,5)$. Decades of past nuclear related activities have left significant local contamination (e.g. nitrate, $\mathrm{U}$, tritium, $\mathrm{Cr}^{6+},{ }^{99} \mathrm{Tc}$ ) in the vadose zone and groundwater within the Hanford Site. Some of this contamination has reached the Columbia River, and there remains the potential for further contaminant migration to the river.

One location of contamination concern is the 300 Area located in the SE corner of the Hanford Site (Figure 1), and situated along $\sim 2 \mathrm{~km}$ of Columbia River shore. There, U fuel rods for Hanford's nuclear reactors were manufactured, along with research and development of chemical processes and testing of materials in several small nuclear reactors (6). Process and research operations were performed on a wide range of materials including non-irradiated and irradiated natural-abundance and enriched $U$ fuels, and depleted $U$ (7). Waste disposal facilities in the northern section of the 300 Area included seepage ponds (used 1943-1975) and trenches (used 1975-1994), as close as 100 $\mathrm{m}$ from the river shore. The disposal of basic and acidic wastes containing a cumulative total of an estimated 38 to 58 metric tons of $\mathrm{U}$, along with greater amounts of $\mathrm{Cu}, \mathrm{F}, \mathrm{Al}$, and nitrate $(8)$ has resulted in vadose zone and groundwater contamination (Figure 2).

As part of a remediation plan for the 300 Area, the former sites of the North Process Pond (1948-1974), South Process Pond (1943-1975) and process trenches were excavated in the 1990's to remove bottom sediments heavily contaminated with U, with the expectation that the 300 Area groundwater U plume would dissipate by natural flushing to the Columbia River on a decadal time scale. Even with removal of the contaminated sediments, the 300 Area U plume has persisted, and over 2004-2006 even appeared to increase slightly in estimated U mass (9). 300 Area groundwater U concentrations are influenced by fluctuations in river stage that drive water-table elevation near the river. Higher $\mathrm{U}$ concentrations at inland wells are commonly observed when the water table is elevated, while near-shore wells show the effect of dilution by river water. Rising $U$ 
concentrations may be the consequence of remobilizing uranium that is sequestered in the lower vadose zone beneath the former waste disposal sites (9-12).

Currently, routine monitoring of $U$ documents concentrations in the Columbia River, but provides limited constraint as to the source and discharge rate of any U. Uranium from nuclear industrial activities covers a wide range of ${ }^{235} U /{ }^{238} U$ and ${ }^{236} U /{ }^{238} U$ ratios due to variable combinations of isotopic enrichment and use in nuclear reactors. In contrast, natural background uranium in groundwater and vadose zone porewater has essentially a constant ${ }^{235} \mathrm{U} /{ }^{238} \mathrm{U}$ ratio (to within $\pm 0.7 \%$ (13, 14)), virtually zero ${ }^{236} \mathrm{U} /{ }^{238} \mathrm{U}$, but variable ${ }^{234} \mathrm{U} /{ }^{238} \mathrm{U}$ due to alpha recoil effects and chemical exchange with mineral grains (15) that provides a discriminator for different sources of groundwater and can be imparted as a signature to surface water.

Our objectives in this paper are to quantify the discharge rate of uranium (U) to the Columbia River from the Hanford Site's 300 Area, and to follow that U down river to assess its fate. Here we present uranium isotopic data ${ }^{234} \mathrm{U} /{ }^{238} \mathrm{U},{ }^{235} \mathrm{U} /{ }^{238} \mathrm{U}$ and ${ }^{236} \mathrm{U} /{ }^{238} \mathrm{U}$ ) for water samples from the Columbia River, collected near the Hanford Site in Washington as well as from sites further downriver from Hanford, and from two major tributaries to the Columbia. We also analyzed groundwater samples from the Hanford 300 Area, one source of $U$ to the Columbia River. The $\mathrm{U}$ isotopic data are used to characterize and quantify the anthropogenic uranium in the samples and to estimate the discharge rate of 300 Area $U$ to the Columbia River. In addition, the isotopic characterization of $U$ provides a means to trace 300 Area sourced uranium downstream and constrain its geochemical behavior.

\section{Sampling and Analytical Methods}

We analyzed samples from traverses across the Columbia at three locations (Figure 1). A traverse near the Vernita Bridge, upstream from Hanford Site contamination, provides a check of background $\mathrm{U}$ isotopic composition. Traverses $\sim 0.5 \mathrm{~km}$ downriver of the 300 Area, and $\sim 5 \mathrm{~km}$ downstream of the Hanford Site adjacent to Richland, WA near its municipal water intake (Richland Pump House $=\mathrm{RPH}$ ) provide opportunities for detection of Hanford derived U. Samples from two irrigation return canals that enter the river at the eastern shore, just upstream and downstream of the 300 Area were analyzed 
to characterize them as a source of $U$ to the river. We also analyzed samples of the Columbia River collected up to $400 \mathrm{~km}$ downstream from the Hanford Site, three collected in October 2004, one collected in November 2004, and one in July 2000 (Figure 4). For comparison we analyzed samples of the Yakima River just upstream of its confluence with the Columbia River (Figure 1) and of the Snake River just above its confluence (Figure 4). To characterize the 300 Area U plume we analyzed four spatially distributed samples (from groundwater monitoring wells and riverbank seeps/springs) representing $U$ contaminated groundwater (Figure 2). The sampling traverses across the Columbia River were conducted on Sept. 9, 2003 (fall 2003) and March 30, 2004 (spring 2004) as part of normal Hanford monitoring.

All groundwater and river water samples were filtered to 0.45 micron. The $U$ was separated using TRU resin (Eichrom Ind.s Inc.) and analyzed for $U$ isotopes using a multi-collector ICP-source mass spectrometer (MC-ICPMS IsoProbe) at Lawrence Berkeley National Laboratory (LBNL) (16, 17). For details see Supporting Information.

\section{Results}

The results of the $U$ isotopic analyses, along with $U$ concentrations and other sample information are provided in Table S1 in the Supporting Information. The samples from the upstream traverse near Vernita Bridge (traverse \#1 Figure 1) have ${ }^{236} \mathrm{U} /{ }^{238} \mathrm{U}<2 \times 10^{-8}$ (Figure 3), and normal ${ }^{235} \mathrm{U}^{238} \mathrm{U}$ consistent with natural sources of $\mathrm{U}$ and minimal contributions from eroded and mobilized fallout-derived ${ }^{236} U$ (see Supporting Information for further discussion of fallout). Across the traverse, measured ${ }^{234} U{ }^{238} \mathrm{U}$ is uniform at $70.60( \pm 0.12) \times 10^{-6}$, and $\mathrm{U}$ concentrations average $0.43 \mu \mathrm{g} / \mathrm{L}$ (Figure 3). This traverse provides baseline $\mathrm{U}$ isotopic compositions and $\mathrm{U}$ concentrations for this study.

The sample traverse just downstream of the 300 Area is divided by an island (traverse \#2, Figures 1 and 2). For the fall 2003 traverse (Figure 3), the two samples from the western channel have detectable ${ }^{236} \mathrm{U}$, with the western-most sample (about $100 \mathrm{~m}$ off shore) having a ${ }^{236} \mathrm{U} /{ }^{238} \mathrm{U}$ of $40 \times 10^{-6}$, while the two samples from the eastern channel have ${ }^{236} U{ }^{238} U<2 \times 10^{-8}$. Samples from the eastern and western ends have low ${ }^{234} U /{ }^{238} U$ compared to the samples from the upstream Vernita Bridge traverse. 
About $5 \mathrm{~km}$ further downstream, the sample traverse at the Richland Pump House (RPH) water intake (traverse \#3, Figure 1) is also divided by an island. Samples from the eastern channel for fall 2003 and spring 2004 (Figure 3) have ${ }^{236} \mathrm{U} /{ }^{238} \mathrm{U}<2 \times 10^{-8}$. Samples from the western channel all have detectable ${ }^{236} \mathrm{U}$, outlining in ${ }^{236} \mathrm{U} /{ }^{238} \mathrm{U}$ the width of the $U$ plume at those times. In the fall 2003 traverse, the peak ${ }^{236} \mathrm{U}^{238} \mathrm{U}$ is higher $\left(34 \times 10^{-6}\right)$ than in the spring 2004 traverse $\left(15 \times 10^{-6}\right)$ and occurs $\sim 100 \mathrm{~m}$ off the western bank. A vertical profile situated $100 \mathrm{~m}$ off the western shore in the spring 2004 RPH traverse indicates that the plume is essentially uniform with depth $\left({ }^{236} U /{ }^{238} U=3.85\right.$ $\times 10^{-6}$ to $4.16 \times 10^{-6}$ ) down to the riverbed (Figure S2 in Supporting Information). Comparing the two RPH traverses, the ${ }^{236} \mathrm{U} /{ }^{238} \mathrm{U}$ peak is considerably higher in the fall 2003 traverse than in the spring 2004 traverse. This suggests that the discharge rate of 300 Area $U$ was higher on the day of the earlier sampling event.

There is variation in ${ }^{234} \mathrm{U} /{ }^{238} \mathrm{U}$ across both the fall 2003 and spring 2004 traverses, with higher ratios in the middle of the river compared to nearer either bank (Figure 3). To the west of the island, the variation in ${ }^{234} \mathrm{U} /{ }^{238} \mathrm{U}$ is associated with high ${ }^{236} \mathrm{U} /{ }^{238} \mathrm{U}$ reflecting the relatively low ${ }^{234} \mathrm{U}^{238} \mathrm{U}\left(<6.5 \times 10^{-5}\right)$ of 300 Area $\mathrm{U}$ contaminated groundwater. To the east of the island, where ${ }^{236} \mathrm{U} /{ }^{238} \mathrm{U}$ is $<2 \times 10^{-8}$, the low ${ }^{234} \mathrm{U} /{ }^{238} \mathrm{U}$ is associated with relatively high $\mathrm{U}$ concentration $(1.25 \mu \mathrm{g} / \mathrm{L}$ compared to a background concentration of $\sim 0.5 \mu \mathrm{g} / \mathrm{L})$. The two major irrigation return canals contribute water with low ${ }^{234} \mathrm{U}^{238} \mathrm{U}\left(\leq 6.5 \times 10^{-5}\right)$ and high $\mathrm{U}$ concentration (3-4 $\left.\mu \mathrm{g} / \mathrm{L}\right)$, consistent with the suggestion that they are the cause of high $\mathrm{U}$ concentrations that have been observed locally at the east side of the river (18).

Downriver samples collected in October 2004, Nov. 2004 and July 2000 have appreciable ${ }^{236} \mathrm{U}$, with ${ }^{236} \mathrm{U} /{ }^{238} \mathrm{U}$ ranging from $0.25 \times 10^{-6}$ to $0.8 \times 10^{-6}$. The October 2004 samples show a systematic decrease downriver in ${ }^{236} U /{ }^{238} U$ (Figure 4). Samples of the Yakima River and the Snake River near their confluences with the Columbia have ${ }^{236} \mathrm{U} /{ }^{238} \mathrm{U}<2 \times 10^{-8}$.

Figure 5A plots ${ }^{236} \mathrm{U} /{ }^{238} \mathrm{U}$ against ${ }^{235} \mathrm{U} /{ }^{238} \mathrm{U}$ for the fall 2003 Richland/300 Area, and spring 2004 Richland traverses. On such a diagram, data falling along a line indicates mixing between two end-members. In the case of the fall 2003 traverses, both the 300 Area river data and the Richland Pump House data trend along a single line suggesting 
mixing between natural $\mathrm{U}$ (normal ${ }^{235} \mathrm{U} /{ }^{238} \mathrm{U}$ and essentially zero ${ }^{236} \mathrm{U} /{ }^{238} \mathrm{U}$ ) and a 300 Area groundwater end-member with high ${ }^{236} U /{ }^{238} U$ and high (enriched) ${ }^{235} U /{ }^{238} U$. Similarly, the spring 2004 data from the Richland traverse trend along a line, but at higher slope, suggesting the contaminant end-member at that time had a higher ${ }^{236} U{ }^{238} U$ and ${ }^{235} \mathrm{U}^{238} \mathrm{U}$ than in fall, 2003.

Groundwater samples from the 300 Area cover a wide range in $U$ isotopic composition, forming an array extending from high ${ }^{236} \mathrm{U} /{ }^{238} \mathrm{U}$ and ${ }^{235} \mathrm{U} /{ }^{238} \mathrm{U}$ toward lower ${ }^{236} \mathrm{U} /{ }^{238} \mathrm{U}$ and ${ }^{235} \mathrm{U} /{ }^{238} \mathrm{U}$ (Figure $5 \mathrm{~B}$ ). This array suggests the groundwater $\mathrm{U}$ plume represents mixing between vadose sources contaminated with irradiated enriched-U fuels, and either vadose sources contaminated with irradiated natural-U fuels or, alternatively, depleted U with essentially zero ${ }^{236} \mathrm{U}$. The mixing lines for the fall 2003 and spring 2004 traverses each intersect the 300 Area groundwater array at separate points. In the case of the fall 2003 traverse, the line passes very near the sample for the North Seep, while for the spring 2004 traverse the line passes through the sample for well 399-4-7. The intersection of the groundwater isotopic line and the river sample trends can be used to estimate the isotopic compositions of the 300 Area $\mathrm{U}$ discharge to the Columbia River at the times of the fall 2003 and spring 2004 traverses. Assuming those isotopic compositions as the contaminant end-members, the percentage of 300 Area $U$ in the river samples from the fall 2003 traverses ranges from 0 to $39 \%$, while for samples from the spring 2004 traverse the percentage ranges from 0 to $20 \%$ (Table S1). The highest percentages of 300 Area U contribution occurred in the west channel, consistent with upstream groundwater discharge through the riverbed between the 300 Area shore and the island on the east. Samples from shallow aquifer sampling tubes along the 300 Area shore reveal high U concentrations (at places to over $200 \mu \mathrm{g} / \mathrm{L}$ ) beneath the near shore Columbia riverbed (9).

\section{U Discharge Rates from the 300 Area to the Columbia River}

The above observations can be used with data for the flow of the Columbia River to estimate values for the discharge rate of contaminant $U$ from the 300 Area to the Columbia River. Using Eq. 1, and the values in Table 1, the $\mathrm{U}$ discharge rate from the 300 Area to the Columbia River at the time of the fall 2003 Traverse is calculated to be 
$2.2 \mathrm{~g} / \mathrm{min}(3.2 \mathrm{~kg} / \mathrm{day})$, while the $\mathrm{U}$ discharge rate for the time of the spring 2004 traverse was $0.34 \mathrm{~g} / \mathrm{min}(0.5 \mathrm{~kg} / \mathrm{day})$. At those times, the $\mathrm{U}$ discharge from the 300 Area was $\sim 4 \%$ and $\sim 0.6 \%$ respectively of the total natural $U$ dissolved load of the Columbia River.

Eq. (1) $\mathrm{U}_{300 \text { Area }}(\mathrm{mg} / \mathrm{sec})=\left(\mathrm{R}_{\text {flow }}\right) \mathrm{x}\left([\mathrm{U}]_{\text {plume }}\right) \mathrm{x}\left(\mathrm{F}_{300}\right.$ area. $) \mathrm{x}(\mathrm{GF})$

where $R_{\text {flow }}$ is the river flow at the time of sampling, $[U]$ is the $U$ plume concentration in the river, $\mathrm{F}_{300}$ Area. is the fraction of 300 Area $\mathrm{U}$ based on its isotopic composition and the appropriate contaminant end-member, and GF is a geometric factor that accounts for the widths of the fall 2003 and spring 2004 river plumes relative to the width of the river west of the island (a factor of $1 / 4$ for fall 2003, and $1 / 5$ for spring 2004), the variable ${ }^{236} \mathrm{U} /{ }^{238} \mathrm{U}$ across the width of the plumes (a factor of $1 / 2$ ), and that about $2 / 3$ of the river flow is to the west of the island (Fig. 3). We estimate the uncertainty in the calculated 300 Area $\mathrm{U}$ discharge rates using Eq. 1 to be on the order of $30 \%$.

The difference between the fall 2003 and spring 2004 calculated discharge rates (2.2 $\mathrm{g} / \mathrm{min}$ vs $0.34 \mathrm{~g} / \mathrm{min}$, respectively) might be attributable to the river stage history just prior to those sampling campaigns. In the case of the 9/9/03 traverse, river stage had been generally falling since the seasonal peak about 2.5 months previous to that sampling on Sept. $9^{\text {th }}$ and was just beginning a period of relative low river stage. This would then likely have resulted in relatively high groundwater head and so high discharge from the 300 Area to the river (19). In contrast, at the time of the spring 2004 traverse, river stage had been at a relative low, and consistently so, for at least 20 days prior to sampling sufficiently long to significantly reduce groundwater head and so discharge. None of the sampling occurred during periods of high river stage when the minimum $U$ discharge rate to the Columbia River would be expected (19). Therefore the calculated values can not be simply extrapolated to a yearly discharge value.

The data for the downriver Columbia samples collected on 10/14/04 (Sharp's Corner, Celilo Village, Rooster Rock) also provide for estimates of the 300 Area U discharge rate. The $\mathrm{U}$ isotopic compositions of all the Columbia River samples collected downstream of McNary Dam are consistent with a contribution $(<1 \%$ of the background $U$ of the Columbia River) from the 300 Area, each falling within 
error of the mixing line for the fall 2003 traverses (Figure 6). Based on the reservoir volume behind McNary dam, and its out-flow, the mean residence time was $\sim 6$ days at the 10/14/04 sampling. The successive downriver dams add an additional $\sim 8$ days. This data set thus provides a time-series of longer-term measures of the average $U$ discharge rate than do the fall 2003 and spring 2004 data, which represent short-term ( $<$ day) snapshots of the U discharge rate. Using Eq. 2 and data in Table 1, the calculated 300 Area $U$ discharge rates based on the successive 10/14/04 sites in downriver order are $1.1 \mathrm{~kg} / \mathrm{day}, 0.74 \mathrm{~kg} /$ day and $0.28 \mathrm{~kg} / \mathrm{day}$, assuming the reservoirs are well-mixed and no loss of $\mathrm{U}$ to particulates.

Eq. (2) $\mathrm{U}_{300 \text { Area }}(\mathrm{mg} / \mathrm{sec})=\left(\mathrm{R}_{\text {flow }}\right) \mathrm{x}\left([\mathrm{U}]_{\text {total }}\right) \times\left(\mathrm{F}_{300}\right.$ Area. $)$

Likewise, the earlier Rooster Rock sample collected in July 2000 gives a 300 Area U discharge rate of $1.39 \mathrm{~kg} /$ day, and the 11/18/04 sample collected at Vancouver gives a discharge rate of $0.68 \mathrm{~kg} / \mathrm{day}$. These values are likely minimums, since we have not accounted for possible exchange with particulates which could reduce dissolved ${ }^{236} U{ }^{238} \mathrm{U}$ between McNary and Bonneville by as much as 9\% (see Supporting Information for discussion).

\section{Discussion}

Other independent estimates of the discharge rate of 300 Area $U$ to the Columbia are comparable to the above values ( 0.34 to $2.2 \mathrm{~g} / \mathrm{min}$ ). Fritz and Arntzen (20) modeled high-frequency measurements of the hydraulic gradient within the Columbia River nearshore hyporheic zone coupled with estimates of uranium concentrations over the period August, 2004 to October, 2005 to calculate U fluxes $\left(\mu \mathrm{g} / \mathrm{min} / \mathrm{m}^{2}\right)$ over various timescales from the 300 Area to the Columbia River. For the period of their study, they calculate a yearly average $U$ flux of between 2.12 and $2.38 \mu \mathrm{g} / \mathrm{min} / \mathrm{m}^{2}$. Peterson et al. (9) averaged these yearly $U$ flux values to calculate an average discharge rate based on their estimate of $0.17 \mathrm{~km}^{2}$ for the area of the groundwater discharge zone offshore of the 300 Area. They arrived at a calculated value of $200 \mathrm{~kg} / \mathrm{yr}$, or a yearly average discharge rate of 0.38 $\mathrm{g} / \mathrm{min}$. Considering the variability of river stage and its affect on $\mathrm{U}$ discharge rate, this 
value is similar to the value $(0.34 \mathrm{~g} / \mathrm{min})$ calculated above for the spring 2004 traverse. Similarly, Fritz and Arntzen (20) calculate uranium flux variation over a $72 \mathrm{hr}$ period (10/22 to 10/25/04). From their Fig. 11, the maximum fluxes occurred over a 15 hour period on $10 / 24 / 04$ and averaged about $12 \mu \mathrm{g} / \mathrm{m}^{2} / \mathrm{min}$, which corresponds to a $U$ discharge rate of $2 \mathrm{~g} / \mathrm{min}$ (and so a total of $\sim 1.8 \mathrm{~kg}$ of $\mathrm{U}$ over that $15 \mathrm{hr}$ period), again quite comparable to the value, $2.2 \mathrm{~g} / \mathrm{min}$, derived from the data for the fall 2004 traverse.

Hamond and Lichtner (21) use a high-resolution, 3D reactive flow and transport model to estimate a $U$ discharge rate of $24 \mathrm{~kg} /$ year $(0.046 \mathrm{~g} / \mathrm{min})$, which would appear to be too low by more than one order of magnitude to support the measured ${ }^{236} \mathrm{U} /{ }^{238} \mathrm{U}$ in the Sharp's Corner sample ( $\sim 1 \mathrm{~kg} / \mathrm{day}$, a minimum). Even their peak instantaneous value of $0.44 \mathrm{~kg} / \mathrm{day}(0.3 \mathrm{~g} / \mathrm{min})$ is low relative to the estimates discussed above. Though their 3D model includes simulations of the effects of dynamic river stage on the release of $U$ from contaminated sediments, they use a source localized within the footprint of the old SPP (south process pond), and do not include other potential and known vadose zone sources (e.g. former NPP's [north process pond] and 316-5 process trenches) and the vadose zone outside these specific areas which may have been contaminated during operation of the ponds by occasional flooding of the Columbia river. In addition, the actual $\mathrm{U}$ inventory within the vadose zone beneath the SPP may have been underestimated. Therefore their model result represents a lower bound on the actual $U$ discharge rate to the Columbia River (21).

The estimated contaminant $U$ fluxes do not pose a significant radiological impact on the Columbia River, since the decay constants of ${ }^{234} U$ and ${ }^{236} U$ differ by a factor of 96 (22). Thus for the same atom ratio to ${ }^{238} \mathrm{U}$, the activity of ${ }^{234} \mathrm{U}$ is $\sim 100$ times greater than ${ }^{236} \mathrm{U}$. All the ${ }^{236} \mathrm{U} /{ }^{238} \mathrm{U}$ measured in Columbia River samples in this study are less than natural ${ }^{234} \mathrm{U} /{ }^{238} \mathrm{U}$ ratios. The additional activity due to ${ }^{236} \mathrm{U}$ in the down-river with the highest ${ }^{236} U /{ }^{238} U$ (the July 2000 Rooster Rock sample) is only about $0.015 \%$, and due to the added $\mathrm{U}$, about $0.8 \%$. However, these estimates provide insight into the effectiveness of the past remediation strategy for 300 Area groundwater, and emphasize the need to understand the processes of $U$ exchange between the aquifer, aquifer sediments and vadose zone sediments, and their interaction with dynamic river stage. 
The total mass of $U$ contained in the 300 Area groundwater plume (defined by $U$ concentrations above $10 \mu \mathrm{g} / \mathrm{L}$ ) has been typically estimated to be around $100 \mathrm{~kg}(9)$. At a discharge rate of between $\sim 24 \mathrm{~kg} / \mathrm{yr}$ to $\sim 200 \mathrm{~kg} / \mathrm{yr}$, it would take from 4 years to less than 1 year to flush the $\mathrm{U}$ plume to the river, therefore the plume must be continuously replenished by $U$ mass transfer processes from the vadose zone/aquifer sediments to groundwater (11). Since the mass of $U$ in the 300 Area plume has changed little (9), the rate of $U$ transfer must approximately balance the $U$ discharge rate to the Columbia River. By better constraining the total net discharge rate of $U$ from the 300 Area to the Columbia River, better constraints on the bulk kinetics of the transfer of $U$ at the scale of the 300 Area can be achieved.

This paper demonstrates that $\mathrm{U}$ isotopic measurements of Columbia River water samples can trace the contribution of $U$ from the 300 Area, and provide estimates of its discharge rate and fate and transport in the Columbia River. However, there are not presently sufficient data to fully characterize how seasonal and shorter term river stage variations relate to $\mathrm{U}$ discharge from the 300 Area plume, and hence it is difficult to arrive at a well-constrained estimate of average annual discharge. River sampling does not require the assumptions needed for extrapolating point measurements in the hyporheic zone to total flux or the assumptions regarding vadose zone source concentrations and flux built into the groundwater transport modeling. Our data indicate that there is minimal loss or exchange of dissolved $U$ from the river to the sediments. The necessary data to better estimate the discharge could be achieved with high precision isotopic measurements of weekly-to-monthly samples of the Columbia below McNary Dam where the contaminant $U$ is most likely well-mixed.

\section{Acknowledgements}

This work was supported by the Assistant Secretary of the Office of Environmental Management, Office of Science and Technology, Environmental Management Science (now Subsurface Biogeochemical Research) Program, of the U.S. Dept. of Energy under Contract DE-AC02-05CH11231 to LBNL and Contract DE-AC06-76RL01830 to PNNL through the Hanford Science and Technology Program.

\section{Supporting Information Available}

Detailed descriptions of the chemical separation and mass spectrometry methods, further discussion of the down river fate of 300 Area $U$, and the contribution of ${ }^{236} U$ from bomb fallout are provided here. Also included are Figure S2 and Table S1 (referred to in 
the text), as well as Table $S 2\left({ }^{238} \mathrm{U}\right.$ and ${ }^{236} \mathrm{U}$ discharge rates), and Table $\mathrm{S} 3$ (decay constants for natural $U$ isotopes). This material is available free of charge via the Internet at http://pubs.acs.org.

\section{References}

(1) Benke, A. C.; Cushing, C. E., Ed.s Rivers of North America, Elsevier/Academic Press, 2005.

(2) Smyth, H. D. Atomic Energy for Military Purposes: The Official Report on the Development of the Atomic Bomb under the Auspices of the United States Government, 1940-1945. Princeton University Press, 1945.

(3) DOE/RL-98-48 Groundwater/Vadose Zone Integration Project Background Information and State of Knowledge. U.S. Dept. of Energy (1999)

(4) Dauble, D. D.; Watson, D. G. Status of fall chinook salmon populations in the midColumbia River, 1948-1992. N. Amer. J. Fish Managem. 1998, 22, 283-300.

(5) National Research Council report: Managing the Columbia River: Instream Flows, Water Withdrawals, and Salmon Survival, The National Academies Press, Washington, D.C., 2004.

(6) DOE/RK-97-1047 Hanford Site Historic District: History of the Plutonium Production Facilities 1943-1990. Battelle Press, Columbus, Ohio, 2003

(7) Gephart, R. E. Hanford; a conversation about nuclear waste and cleanup. ISBN 157477-134-5, Battelle Press, Columbus Ohio, 2003.

(8) DOE/RL-2005-47, Rev. 1. 300-FF-5 Operable Unit Limited Field Investigation Plan. U.S. Department of Energy, Richland, Washington, 2005

(9) Peterson, R. E.; Rockhold, M. L.; Serne, R. J.; Thorne, P. D.; Williams, M. D. Uranium Contamination in the Subsurface Beneath the 300 Area, Hanford Site, Washington, PNNL-17034, Pacific Northwest National Laboratory: Richland, WA, 2008

(10) Hartman, M. J.; Morasch, L. F.; and Webber, W. D.. Hanford Site Groundwater Monitoring for Fiscal Year 2004. PNNL-15070, Pacific Northwest National Laboratory, Richland, WA., 2005.

(11) Zachara, J. M.; Davis, J. A.; Liu, C.; McKinley, J. P.; Qafoku, N.; Wellman, D. M.; Yabusaki, S. B. Uranium Geochemistry in Vadose Zone and Aquifer Sediments from the 300 Area Uranium Plume. PNNL-15121, Pacific Northwest National Laboratory, Richland, WA. 2005 
(12) Zachara, J.; Brown, C.; Christensen, J.; Davis, J. A.; Dresel, E.; Liu, C.; Kelly, S.; McKinley, J.; Serne, J.; and Um, W. A Site-Wide Perspective on Uranium Geochemistry at the Hanford Site. PNNL-17031. 2007.

(13) Stirling, C. H.; Andersen, M. B.; Potter, E.-K.; Halliday, A. N. Low-temperature isotopic fractionation of uranium. Earth Planet. Sci. Lttrs., 2007, 264, 208-225.

(14) Weyer, S.; Anbar, A. D.; Gerdes, A.; Gordon, G. W.; Algeo, T. J.; Boyle, E. A. Natural fractionation of ${ }^{238} \mathrm{U} /{ }^{235} \mathrm{U}$. Geochim. Cosmochim. Acta, 2008, 72, 345-359.

(15) Maher, K.; DePaolo, D. J.; Christensen, J. N. U-Sr isotopic speedometer: Fluid flow and chemical weathering rates in aquifers. Geochim. Cosmochim. Acta, 2006, 70, 44174435 .

(16) Christensen, J. N.; Dresel, P. E.; Conrad, M. E., Maher, K. and DePaolo, D. J. Identifying the sources of subsurface contamination at the Hanford Site in Washington using high-precision uranium isotopic measurements. Environ. Sci. Technol. 2004, 38, 3330-3337.

(17) Christensen, J. N., Conrad, M. E., DePaolo, D. J., Dresel, P. E. Isotopic studies of contaminant transport at the Hanford Site, Washington. Vadose Zone J., 2007, 6, 10181030 .

(18) Poston T. M., Hanf, R. W.; Dirkes, R. L.; and Morasch, L. F., Ed.s Hanford Site Environmental Report for Calendar Year 2001. PNNL-13910, Pacific Northwest National Laboratory, Richland, WA. 2002

(19) Yabusaki, S. B.; Fang, Y.; and Waichler, S. R. Building conceptual models of fieldscale uranium reactive transport in a dynamic vadose zone-aquifer-river system. Water Resources Research 2008, 44, W12403, doi:10.1029/2007WR006617.

(20) Fritz, B. G.; Arntzen, E. V. Effect of Rapidly Changing River Stage on Uranium Flux through the Hyporheic Zone. Ground Water 2007, 45, 753-760.

(21) Hammond, G. E. and Lichtner, P. C. Field-Scale Model for the Natural Attenuation of Uranium at the Hanford 300 Area using High Performance Computing. Water Resources Research 2010, 46, W09527, doi:10.1029/2009WR008819

(22) Friedlander, G.; Kennedy, J.W.; Macias, E.S. and Miller, J.M. Nuclear and Radiochemistry, $3^{\text {rd }}$ edition, John Wiley and Sons, 1981

(23) USGS Instantaneous Data Archive for the Columbia River below Priest Rapids Dam, WA http://ida.water.usgs.gov/ida/available_records.cfm?sn=12472800

(24) USACE Lower Columbia dams, average water discharges for Oct. 2004 http://www.nwd-wc.usace.army.mil 


\section{Figure Captions}

Figure 1. Map of the Hanford Site showing locations of sampling traverses across the Columbia River: (1) Vernita Bridge, (2) $0.5 \mathrm{~km}$ downstream of the 300 Area, (3) at the Richland Pump House. The red square represents sampling locality for the Yakima River.

Figure 2. Map of the 300 Area (modified from (10) showing locations of sampled wells, seeps/springs, and irrigation return canals. Also shown are contours of $U$ concentration $(\mu \mathrm{g} / \mathrm{L})$ in the groundwater for Dec. 2003.

Figure 3. Sampling traverses across the Columbia River near the Vernita Bridge (top two panels), $0.5 \mathrm{~km}$ downstream of the 300 Area (middle two panels), and at the Richland Pump House (bottom two panels). Panels on the left display measured ${ }^{236} \mathrm{U} /{ }^{238} \mathrm{U}$, while the right hand panels present ${ }^{234} U /{ }^{238} U$ along with $U$ concentrations (numbers by data points, $\mu \mathrm{g} / \mathrm{L}$ ). In the bottom two panels, data for the Sept. 9, 2003 and March 30, 2004 sample traverses are displayed. The horizontal green line in the bottom right panel represents the ${ }^{234} \mathrm{U} /{ }^{238} \mathrm{U}$ at Vernita Bridge at the time of the March 30 Richland traverse.

Figure 4. Map of the lower Columbia River showing the locations of river samples collected in Oct. 2004 and a single sample collected in July 2000. Indicated by each downriver sample location are figures for ${ }^{236} U /{ }^{238} U$ and $U$ concentration $(\mu \mathrm{g} / \mathrm{L})$.

Figure 5. ${ }^{236} \mathrm{U} /{ }^{238} \mathrm{U}\left(\mathrm{x} 10^{6}\right)$ vs. ${ }^{235} \mathrm{U} /{ }^{238} \mathrm{U}$. (A) Data for the sampling traverses at the Vernita Bridge (orange), $0.5 \mathrm{~km}$ downstream of the 300 Area (red), and at the Richland Pump House (9/9/03 black, 3/30/04 green). (B) Data for groundwater samples (wells and seeps/springs) from the 300 Area uranium plume (blue circles). Data from A included for comparison.

Figure 6. Expanded view of Figure 4 displaying $U$ isotopic compositions of samples of the Columbia River downriver of McNary Dam collected in July 2000, October 2004, and Nov. 2004 (blue circles) plotted with data for samples with low or essentially zero ${ }^{236} U{ }^{238} U$ from the $9 / 9 / 03$ (black squares) and 3/30/04 (green squares) sampling traverses. Black and green lines are best-fit lines from Fig. 5 to the 9/9/03 and 3/30/04 samples respectively (includes higher ${ }^{236} \mathrm{U} /{ }^{238} \mathrm{U}$ samples that plot off this figure, see Fig. 5). The purple line represents the lower portion of the locus of the $U$ isotopic compositions of variably spent natural $U$ fuels, while spent enriched $U$ fuels would plot off the diagram to the upper left (black arrow). 


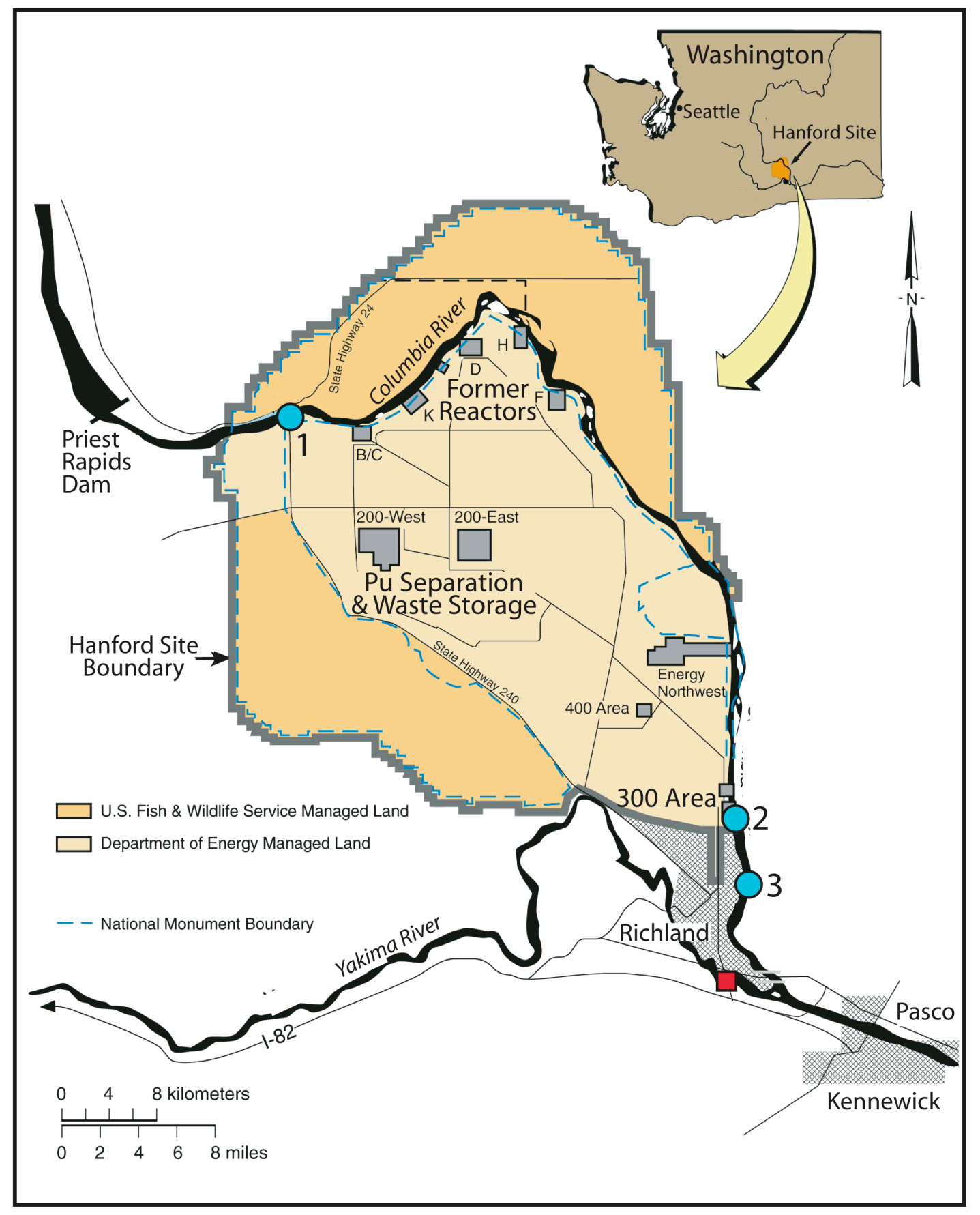

Figure 1. 


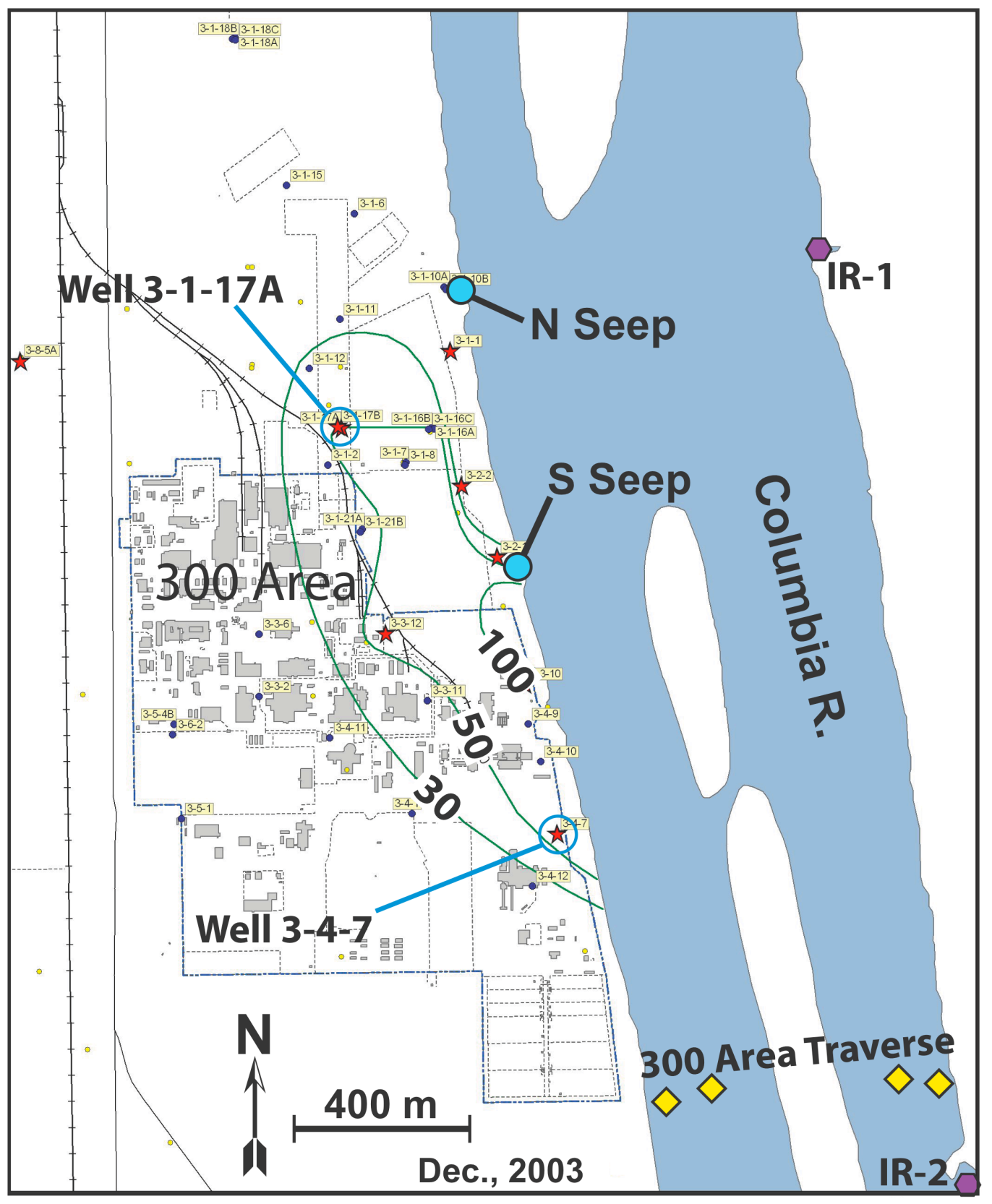

Figure 2. 


\section{Vernita Bridge Traverse, Fall 2003}
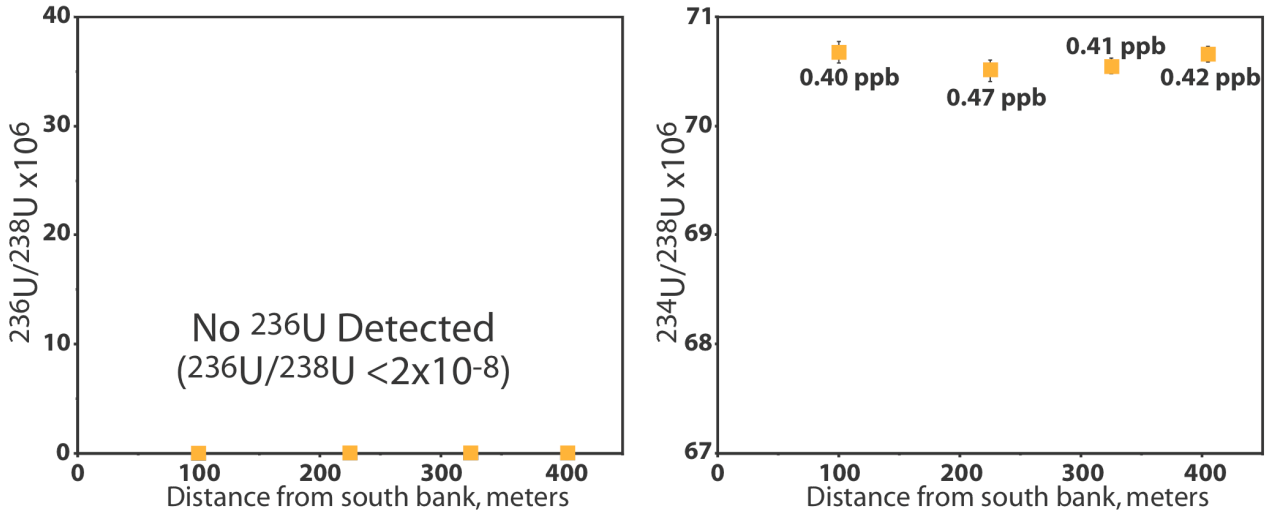

Just South of the 300 Area, Fall 2003
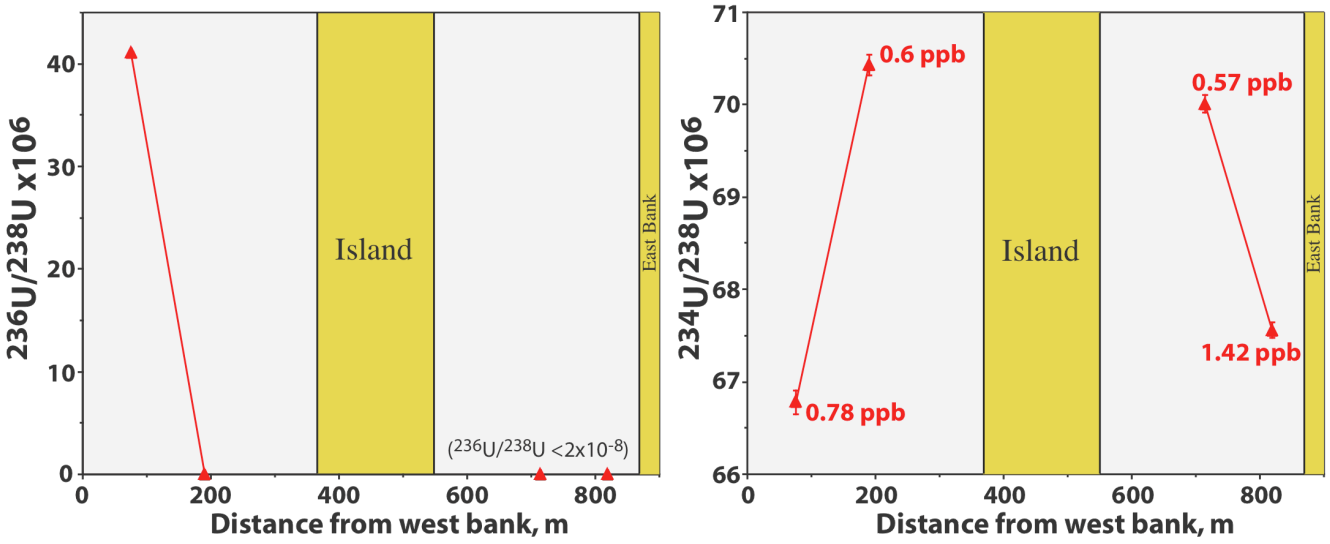

Richland Pump House
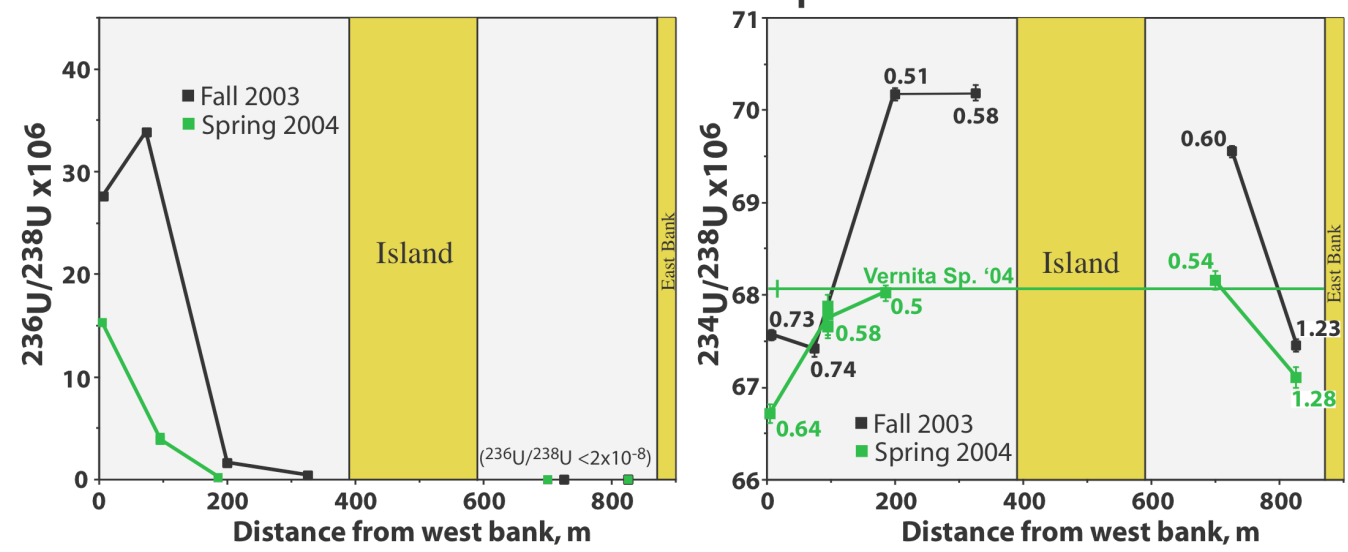

Figure 3. 


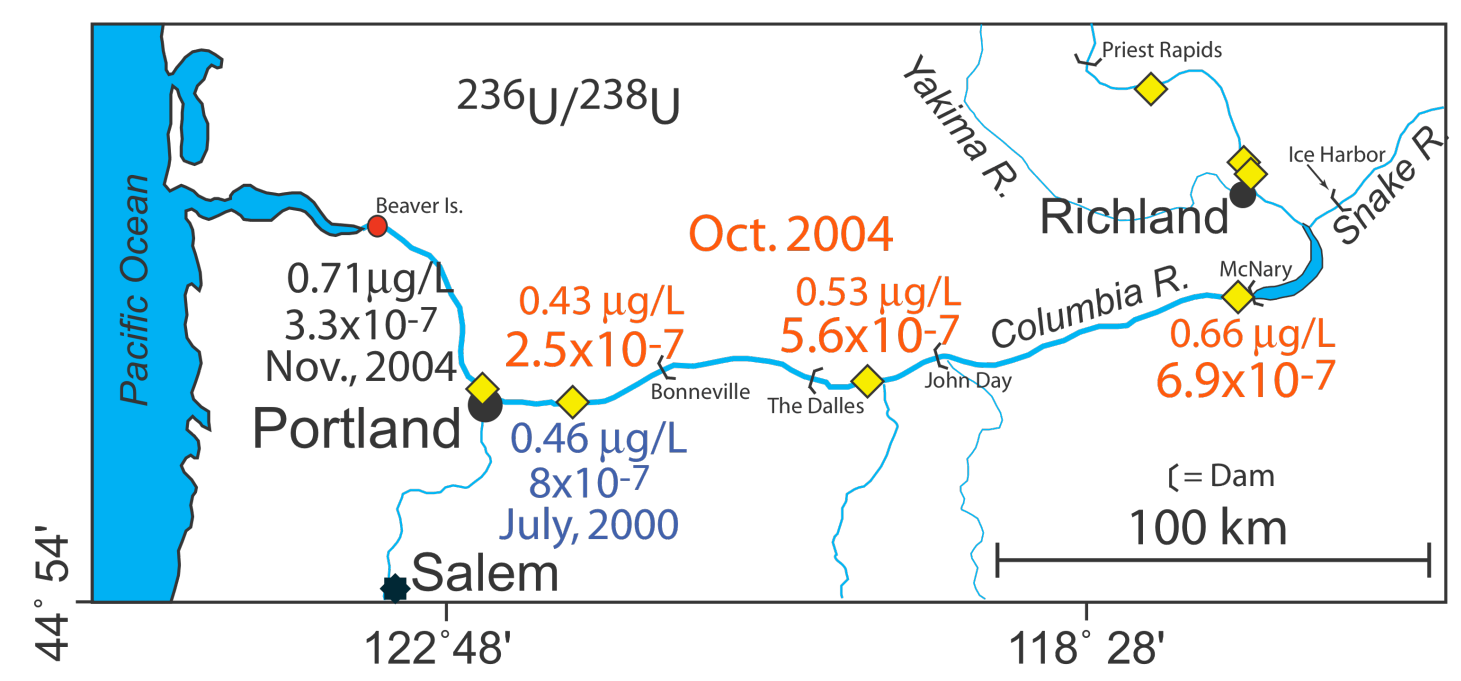

Figure 4. 

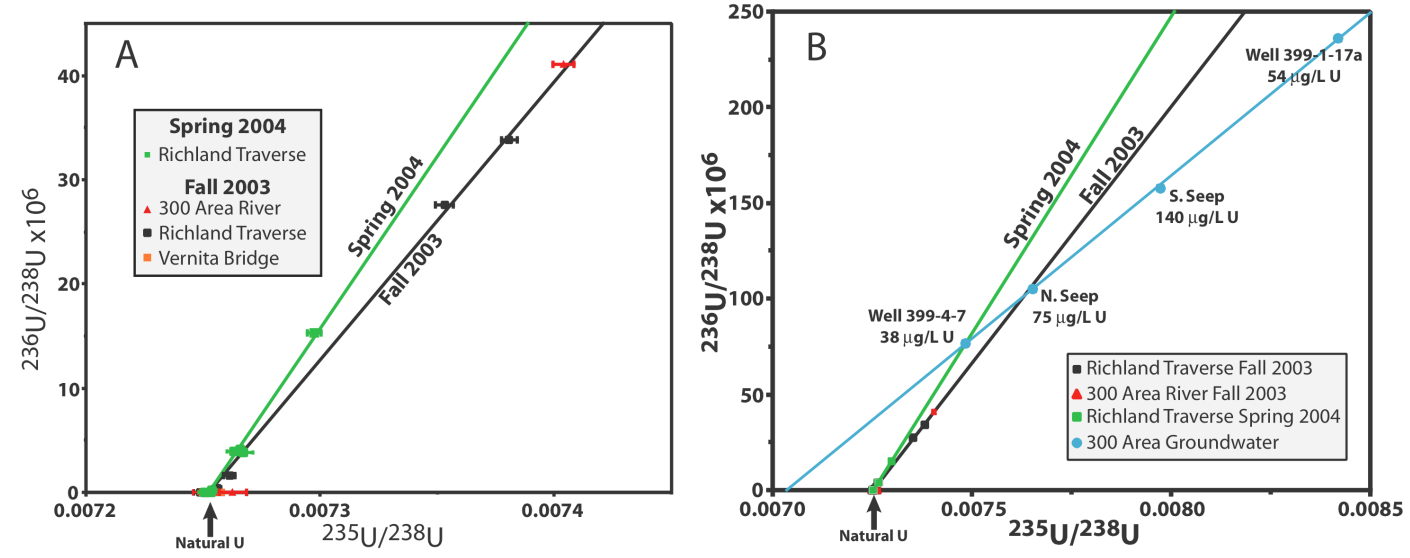

Figure 5. 


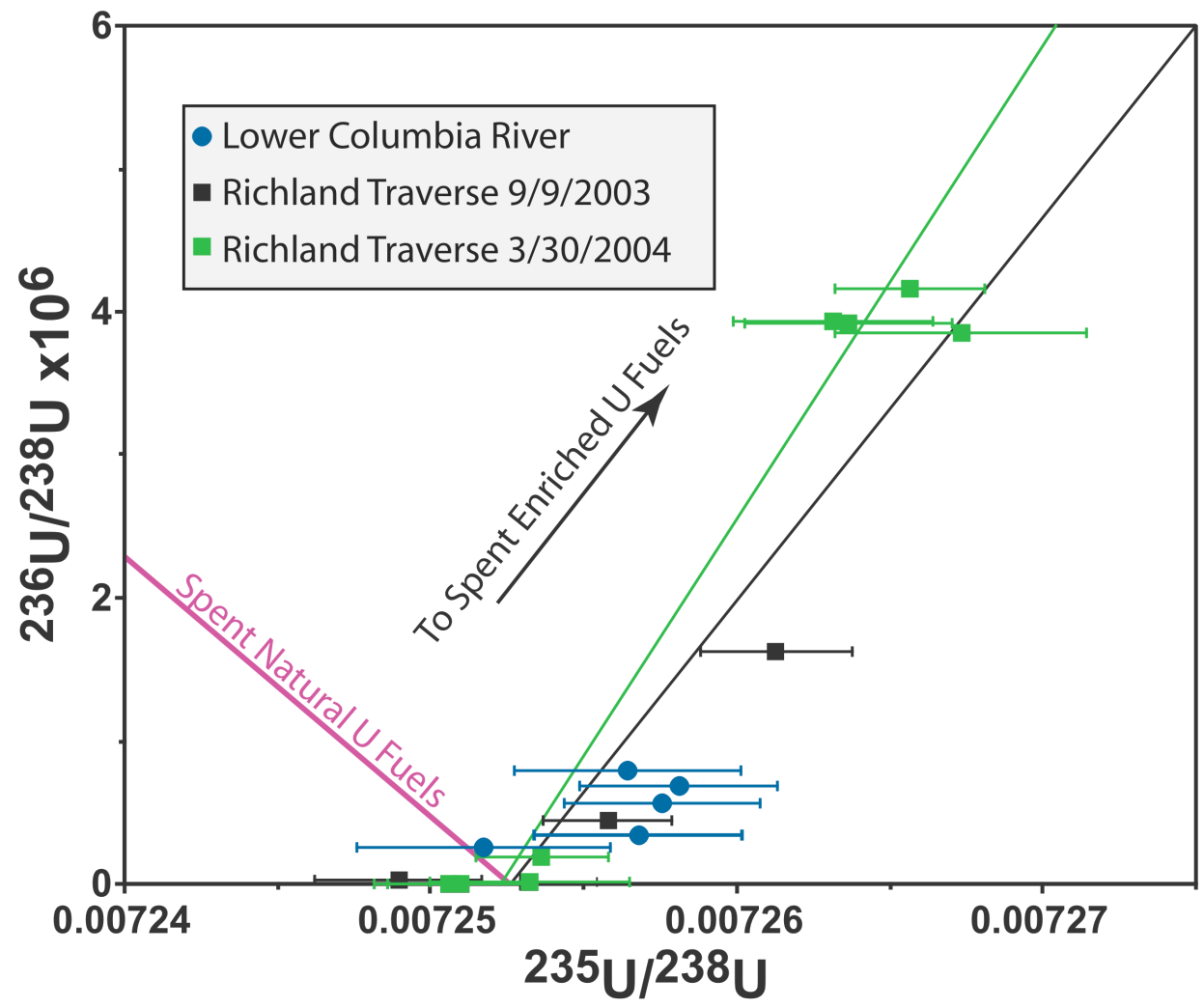

Figure 6. 
Table 1. Data used for calculation of the 300 Area $U$ discharge rates to the Columbia River shown in last column.

\begin{tabular}{|l|l|c|l|l|l|l|}
\hline Location & $\begin{array}{l}\text { Date } \\
\mathbf{( m / d} / \mathbf{y})\end{array}$ & $\mathbf{R}_{\text {flow }}, \mathbf{~ m}^{3} / \mathbf{s e c}$ & $\begin{array}{l}{[\mathbf{U}],} \\
\mathbf{m g} / \mathbf{L}\end{array}$ & $\mathbf{F}_{\mathbf{3 0 0} \text { Area }}$ & $\mathbf{G F}$ & $\begin{array}{l}\text { Calc 300 Area } \\
\text { U discharge rate }\end{array}$ \\
\hline $\begin{array}{l}\text { Transect near the Richland } \\
\text { Pump House }\end{array}$ & $09 / 09 / 03$ & $1784^{*}$ & 0.74 & 0.33 & 0.083 & $3.2 \mathrm{~kg} / \mathrm{day}$ \\
\hline $\begin{array}{l}\text { Transect near the Richland } \\
\text { Pump House }\end{array}$ & $03 / 30 / 04$ & $2039^{*}$ & 0.6 & 0.07 & 0.067 & $0.5 \mathrm{~kg} / \mathrm{day}$ \\
\hline Sharps Corner, McNary Dam & $10 / 14 / 04$ & $2988^{\dagger}$ & 0.66 & 0.0066 & ----- & $1.1 \mathrm{~kg} / \mathrm{day}$ \\
\hline Celilo Village, The Dalles & $10 / 14 / 04$ & $3028^{\dagger}$ & 0.53 & 0.0053 & ----- & $0.74 \mathrm{~kg} / \mathrm{day}$ \\
\hline Rooster Rock, Bonneville & $10 / 14 / 04$ & $3128^{\dagger}$ & 0.43 & 0.0024 & ----- & $0.28 \mathrm{~kg} / \mathrm{day}$ \\
\hline Rooster Rock, Bonneville & $07 /--/ 00$ & $4923^{\$}$ & 0.46 & 0.0076 & ----- & $1.39 \mathrm{~kg} / \mathrm{day}$ \\
\hline Vancouver, WA & $11 / 18 / 04$ & $3534^{\$}$ & 0.71 & 0.0031 & ----- & $0.68 \mathrm{~kg} / \mathrm{day}$ \\
\hline
\end{tabular}

*(23) For sampling date; ${ }^{\dagger}(24)$ Average for Oct. 2004; $\$(24)$ Average for sampling month $\mathrm{R}_{\text {flow }}=$ river flow at time of sampling: $\mathrm{F}_{300 \text { Area }}=$ the fraction of 300 Area $\mathrm{U} ; \mathrm{GF}=$ factor to account for the geometry of plume relative to the river flow 


\section{Brief}

Uranium isotopes, in particular ${ }^{236} \mathrm{U}$, are used to quantify and track the contribution of $U$ from the Hanford Site to the Columbia River. 
Supporting Information

\section{Isotopic Tracking of Hanford 300 Area Derived Uranium in the Columbia River}

John N. Christensen ${ }^{1}$, P. Evan Dresel ${ }^{2 a}$, Mark E. Conrad ${ }^{1}$, Gregory W. Patton ${ }^{2}$, and Donald J. DePaolo ${ }^{1,3}$

1. Lawrence Berkeley National Laboratory, 1 Cyclotron Rd., Berkeley, CA 94720

2. Pacific Northwest National Laboratory, MS K6-96, Richland, WA 99352

3. University of California Berkeley, Berkeley, CA 94720

*Corresponding author, phone: 510-486-6735, FAX 510-486-5496

e-mail: jnchristensen@lbl.gov

Prepared for Environmental Science \& Technology, 10/8/2010

\section{Supporting Information}

Number of pages: 8

Number of Tables: 3

Number of Figures: 5

\section{Contents}

Analytical Methods

Down river fate of 300 Area $U$

Bomb Fallout as a source of ${ }^{236} U$ to the Columbia River

\section{References}

\section{Figure S1}

Figure S2

Figure S3

Figure $\mathrm{S4}$

Figure S5

\section{Table S1}

Table S2

Table S3

\footnotetext{
${ }^{\text {a }}$ Current address: Victoria State Department of Primary Industries, PO Box 3100, Bendigo Delivery Centre, Bendigo, Victoria 3554, Australia
} 


\section{Analytical Methods}

All groundwater and river water samples were filtered to 0.45 microns. All sample evaporation and chemical separation procedures described below were conducted in a Class 10 ULPA filtered laminar flow fume hood situated in a class 1000 clean room. All acids $\left(\mathrm{HCl}, \mathrm{HF}, \mathrm{HCLO}_{4}\right.$, and $\left.\mathrm{HNO}_{3}\right)$ used were high-purity "Baseline" grade from Seastar Chemicals Inc., and water for acid-dilution was $18.2 \mathrm{M} \Omega \mathrm{cm}$ produced by a Millipore Inc. Milli-Q system. A portion of the samples (100 $\mathrm{ml}$ for river samples [except for Portland 11/18/04 and SR-1, which were $250 \mathrm{ml}$ and $200 \mathrm{ml}$ respectively], and $<2 \mathrm{ml}$ for the 300 Area groundwater samples) were evaporated down in Teflon jars and/or vials, taken up in $2 \mathrm{ml} 8 \mathrm{~N} \mathrm{HNO}_{3}$, and dried down again. The samples were then taken up again in $\sim 300 \mu \mathrm{l} 1.5 \mathrm{~N} \mathrm{HNO}_{3}$ for loading and separation on small-volume Teflon columns (created with heat-shrink Teflon shrunk onto stainless steel forms) using a $0.15 \mathrm{ml}$ bed of TRU-SPEC (Eichrom Industries Inc.) resin and a scaled down version of the procedure from Luo et al. (1997). The TRU resin was pre-cleaned in bulk in a Teflon bottle by repeated cycles of agitation, settling, and decanting with DI water. Prior to sample loading, the pre-cleaned TRU resin was further cleaned in column with $1.2 \mathrm{ml}$ of $0.2 \mathrm{M}$ HCL and then $1.2 \mathrm{ml}$ of $0.3 \mathrm{M} \mathrm{HF}$. After these cleaning steps, the resin beds were conditioned with $1.2 \mathrm{ml}$ of $1.5 \mathrm{M} \mathrm{HNO}_{3}$ in preparation for sample loading. The samples were centrifuged down and the supernate pipetted onto the columns. The columns were eluted with $2 \mathrm{ml}$ of $1.5 \mathrm{M} \mathrm{HNO}_{3}$, and the separated $\mathrm{U}$ collected off the column with 1.6 $\mathrm{ml}$ of $0.5 \mathrm{M} \mathrm{HF}$. The separation procedure produces $>95 \%$ yields of $U$. A drop of perchloric acid is added to the collected $\mathrm{U}$ cut, and dried down at $160^{\circ} \mathrm{C}$ to drive off the perchloric acid and destroy any organics. The $U$ is taken up in one drop concentrated nitric, evaporated to near dryness and diluted with $0.3 \mathrm{~N}$ nitric to a $\mathrm{U}$ concentration of 20 ppb. The solution $U$ concentration is checked on the IsoProbe and adjusted, if necessary, to match the concentration $(20 \mathrm{ppb})$ of the natural $\mathrm{U}$ standard described below. For all steps, brand new, cleaned Savillex Teflon ware was used for each sample, and fresh resin was used for each sample separation.

The isotopic compositions $\left({ }^{234} \mathrm{U} /{ }^{238} \mathrm{U},{ }^{235} \mathrm{U} /{ }^{238} \mathrm{U}\right.$, and $\left.{ }^{236} \mathrm{U} /{ }^{238} \mathrm{U}\right)$ of the separated $\mathrm{U}$ were measured using a multi-collector ICP source mass spectrometer (MC-ICPMS IsoProbe originally manufactured by Micromass) at Lawrence Berkeley National 
Laboratory (LBNL) using the procedure described in Christensen et al. (2004), and Christensen et al. (2007) and described in detail below. The IsoProbe is equipped with a set of 9 movable Faraday cups, each with amplifiers using $10^{11} \mathrm{Ohm}$ resistors, and an axial Daly ion counting photomultiplier system situated behind a wide-angle retardation potential lens (WARP filter) providing high-abundance sensitivity of about $100 \mathrm{ppb}$ at 1 AMU below mass 238. The IsoProbe has a mass resolution $(\mathrm{m} / \Delta \mathrm{m})$ of $445(10 \%$ peak height definition), increasable with an adjustable entrance slit, and an adjustable axial slit (for this study, the slits were in their open positions). Samples solutions were introduced to the IsoProbe with an Aridus (CETAC Inc.) desolvation system with a low flow ( $\sim 50$ $\mu 1 /$ min) Teflon nebulizer. This desolvation system separates the solute from the solvent, and sends a dry sample-aerosol into the plasma, increasing sample use efficiency and greatly reducing oxide and hydride production.

Two separate static simultaneous measurement routines are used for ${ }^{234} \mathrm{U},{ }^{235} \mathrm{U},{ }^{236} \mathrm{U}$ and ${ }^{238} \mathrm{U}$, one routine with ${ }^{234} \mathrm{U}$ on the axial Daly, ${ }^{235} \mathrm{U}$ on High 1 Faraday and ${ }^{238} \mathrm{U}$ on the High 3 Faraday; and the second with ${ }^{236} \mathrm{U}$ on the axial Daly, ${ }^{235} \mathrm{U}$ on the Low 1 faraday and ${ }^{238} \mathrm{U}$ on the High 2 Faraday. This data is used to calculate ${ }^{234} U /{ }^{238} U,{ }^{235} U /{ }^{238} U$ and ${ }^{236} \mathrm{U} /{ }^{238} \mathrm{U}$ atomic ratios. Sample analytical runs are bracketed with runs of a natural uranium secular equilibrium standard ( $U$ ore from the Schwartzwalder Mine, CO provided by W. Sharp, Berkeley Geochronology Center) diluted to $20 \mathrm{ppb}$ in $0.3 \mathrm{M}$ $\mathrm{HNO}_{3}$ from a 6 ppm stock solution with no chemical separation (more recently $30 \mathrm{ppb}$ is used, which affects only the Snake River sample SR-1 and the Columbia River sample collected at Vancouver on 11/18/04). For isotopic analysis the samples are brought up in $0.3 \mathrm{~N} \mathrm{HNO} 3$, and matched in concentration to that of the $U$ standard (e.g. $20 \mathrm{ppb}$ ) within $20 \%$. The in-house secular equilibrium $U$ standard is used to correct for instrumental mass fractionation, Daly/Faraday gain, the contribution of ${ }^{235} \mathrm{U}^{1} \mathrm{H}+$ to mass 236, and peak tailing from the ${ }^{238} \mathrm{U}\left(\&{ }^{235} \mathrm{U}\right)$ beam onto mass 236 . The measured isotopic ratios of the sample unknowns are mass fractionation corrected with the measured ${ }^{238} \mathrm{U} /{ }^{235} \mathrm{U}$ of the natural $U$ standard using an assumed ${ }^{238} \mathrm{U} /{ }^{235} \mathrm{U}$ ratio of 137.88 for the $\mathrm{U}$ standard and an exponential mass fractionation law. For Daly/Faraday gain correction for both ${ }^{236} \mathrm{U} /{ }^{238} \mathrm{U}$ and ${ }^{234} \mathrm{U} /{ }^{238} \mathrm{U}$ ratios ( since ${ }^{234} \mathrm{U}$ and ${ }^{236} \mathrm{U}$ are measured with the Daly ion counting system, and ${ }^{238} \mathrm{U}$ on a Faraday) the internally mass fractionated corrected ${ }^{234} \mathrm{U} /{ }^{238} \mathrm{U}$ ratio of the 
secular equilibrium $U$ standard is compared to the expected ${ }^{234} U /{ }^{238} U$ atomic ratio for secular equilibrium $\left(54.83 \times 10^{-6}\right)$, and at the time of the analyses was typically on the order of $6 \%$, with a $2 \mathrm{~s}$ uncertainty during an analytical session of about $1 \%$. As part of each analysis of the standard $U$ solution and the unknown samples, a blank solution of $0.3 \mathrm{M} \mathrm{HNO3}$ is measured in a single one-minute integration to establish background intensities at masses 234, 235, 236 and 238 that are subtracted from the measured ion beams. In addition, at the start of the analysis with the full ion beam, an off-peak background is taken on the detector array at a half mass below centered mass. At mass 236, during sample analysis there are contributions from background (accounted for by the blank measurement), ${ }^{235} \mathrm{U}^{1} \mathrm{H}^{+}$(uranium hydride), and from tailing from the ${ }^{238} \mathrm{U}$ beam in addition to any ${ }^{236} \mathrm{U}$ in the sample. The contributions from ${ }^{235} \mathrm{U}^{1} \mathrm{H}^{+}$, up-mas tailing from ${ }^{235} \mathrm{U}$ and down-mass tailing from ${ }^{238} \mathrm{U}$ is accounted for by measurement of the apparent ${ }^{236} \mathrm{U} /{ }^{238} \mathrm{U}$ of the secular equilibrium standard. After mass fractionation correction, and Daly-Faraday gain correction, typically the apparent ${ }^{236} \mathrm{U} /{ }^{238} \mathrm{U}$ of the $\mathrm{U}$ standard is about 2 to $3 \times 10^{-8}$ (it is expected that the actual ${ }^{236} \mathrm{U} /{ }^{238} \mathrm{U}$ of the natural $\mathrm{U}$ ore would be on the order $10^{-10}$ to $10^{-12}$ [Wilcken et al. 2007; Steier et al. 2008]) reflecting the combined contributions from $\mathrm{U}$ hydride and tailing. The apparent ${ }^{236} \mathrm{U} /{ }^{238} \mathrm{U}$ of the $\mathrm{U}$ standard is used to correct the fractionated corrected ${ }^{236} \mathrm{U} /{ }^{238} \mathrm{U}$ measured of the sample. If after correction, the residual ${ }^{236} \mathrm{U} /{ }^{238} \mathrm{U}$ of the sample is greater than $2 \times 10^{-8}$ (effectively twice the typical apparent ${ }^{236} \mathrm{U} /{ }^{238} \mathrm{U}$ ratio of the secular equilibrium $\mathrm{U}$ standard), that ratio is reported. Otherwise, the sample ${ }^{236} \mathrm{U}^{238} \mathrm{U}$ is reported as less than $2 \times 10^{-8}$, even though often the residual ${ }^{236} \mathrm{U} /{ }^{238} \mathrm{U}$ after correction for samples in this study is often different from zero outside the uncertainties (Table S1). Our lower limit of $2 \times 10^{-8}$ is similar to other quoted limits for ${ }^{236} \mathrm{U}^{238} \mathrm{U}$ measurement by MC-ICPMS ((IsoProbe: Buchholz et al. 2007 Note they quote the limit as a ${ }^{236} \mathrm{U}^{235} \mathrm{U}$ ratio of $2 \times 10^{-6}$ which is equivalent to a ${ }^{236} \mathrm{U} /{ }^{238} \mathrm{U}$ ratio of $1.5 \times 10^{-8}$ ) and $1 \times 10^{-8}$ (Boulyga et al. 2006). The uncertainty of the reported corrected ${ }^{236} U /{ }^{238} U$ of the samples includes the measurement uncertainty, the reproducibility of the Daly/Faraday gain, the uncertainty in the fractionation correction and the uncertainty in the apparent ${ }^{236} U /{ }^{238} U$ of the natural $U$ standard. Uranium concentrations were determined by comparison to the above secular equilibrium natural 
$\mathrm{U}$ standard of known concentration used for isotopic reference (see Christensen et al. 2004, Christensen et al. 2007).

We have no mass scans available from the time when nearly all the samples in this paper were analyzed. However, we present here (Figures S1A and S1B) scans from two samples (Vancouver (11/18/04) and Snake River) that were analyzed for revision of the paper. At that time abundance sensitivity was worse $(\sim 8 \mathrm{x})$ than for the earlier analyses (the rest of the samples presented in the paper were analyzed under conditions where the abundance sensitivity was $\sim 100 \mathrm{ppb}$ ) due to degraded flight tube pressure. We also present mass scans for a blank solution (Figure S1D) and for the natural U secular equilibrium standard described above (Figure S1C) used for data correction.

Figure S1D for the blank solution (0.3 M HNO3) shows the background at mass 236 (about $10 \mathrm{cps}$ ), and shows the base of the peak at mass 237 due to ${ }^{197} \mathrm{Au}{ }^{40} \mathrm{Ar}+$ (gold argide) (at the scale of Figure S1A, the top of the 237 peak can be seen). Figure S1C shows the combined effects of tailing down from the ${ }^{238} \mathrm{U}$ ion beam, tailing up from the ${ }^{235} \mathrm{U}$ ion beam, background at mass 236 , and ${ }^{235} \mathrm{U}^{1} \mathrm{H}^{+}$for the natural $\mathrm{U}$ secular equilibrium standard, showing a small peak at mass 236. As described above, measurement and correction of this peak is used to correct the measured mass 236 of sample unknowns to provide corrected ${ }^{236} \mathrm{U} /{ }^{238} \mathrm{U}$ ratios. Figure $\mathrm{S} 1 \mathrm{~B}$ shows the mass scan for the sample of the Snake River with ${ }^{236} \mathrm{U} /{ }^{238} \mathrm{U}<2 \times 10^{-8}$ (actual corrected value is $7.2( \pm 9.8) \times 10^{-9}$, not quite distinguishable from zero). Figure S1A is a mass scan for the Columbia River sample collected at Vancouver, WA on 11/18/04 which has a corrected ${ }^{236} \mathrm{U} /{ }^{238} \mathrm{U}$ of $3.3( \pm 0.3) \times 10^{-7}$. The uncertainty in this value of $9 \%$ is several times larger than for the samples with comparable ${ }^{236} U /{ }^{238} U$ analyzed earlier, due to the degraded abundance sensitivity. However, even under these conditions, a lower cutoff of $2 \times 10^{-8}$ is still reasonable (though certainly less conservative than before). In Table S1, the corrected ${ }^{236} \mathrm{U} /{ }^{238} \mathrm{U}$ (along with $2 \mathrm{~s}$ uncertainties) of samples where that ratio is $<2 \times 10^{-8}$ are reported, but are only used in the discussion of fallout ${ }^{236} \mathrm{U}$ provided below.

\section{Down river fate of 300 Area $U$}

The systematic decrease in ${ }^{236} \mathrm{U} /{ }^{238} \mathrm{U}$ of the Oct. 2004 down-river samples with distance from the Hanford Site 300 Area (Figure 4) provides some constraints on the 
geochemical fate of $U$ within the Columbia River. Figure $S 3$ plots the ${ }^{236} U{ }^{238} U$ of the three Oct. 2004 down-river samples against the reciprocal of their $U$ concentrations and compares that relationship to ${ }^{236} \mathrm{U} /{ }^{238} \mathrm{U}$ vs. the Oct. 2004 average water discharge rates for the three appropriate dams (McNary, The Dalles \& Bonneville). In each case the data fall along a straight line, but the increase in water discharge rate between McNary and Bonneville $(+5 \%)$ is much less than the percentage decrease in $U$ concentration $(-35 \%)$, undermining a case for simple dilution. For if the downriver decrease in ${ }^{236} \mathrm{U} /{ }^{238} \mathrm{U}$ were due only to dilution by water with dissolved $\mathrm{U}$ with essentially zero ${ }^{236} \mathrm{U} /{ }^{238} \mathrm{U}$, this would imply an input of $5259 \mathrm{~m}^{3} / \mathrm{sec}$ and removal of $5110 \mathrm{~m}^{3} / \mathrm{sec}$ along that stretch of the Columbia (for a net increase in discharge of $150 \mathrm{~km}^{3} / \mathrm{sec}$ ), which is highly unlikely.

A second possibility is that the decrease in ${ }^{236} \mathrm{U} /{ }^{238} \mathrm{U}$ is due to a combination of dilution and absorptive loss of $U$ to particulates. Between McNary and Bonnevile the discharge rate of ${ }^{238} \mathrm{U}$ decreases by $32 \%$ while that of ${ }^{236} \mathrm{U}$ decreases by $75 \%$ (Table S2). If this is due to $\mathrm{U}$ loss, to support this differential drop in ${ }^{238} \mathrm{U}$ and ${ }^{236} \mathrm{U}$ discharge rates (assuming no significant change in 300 Area discharge rate, see below) would suggest that the average water entering the Columbia river between McNary and Bonneville dams (e.g. from tributaries or groundwater) at that time had a dissolved $U$ concentration of between $\sim 6-7.5 \mu \mathrm{g} / \mathrm{L}$. At the moment there is no evidence for such high $U$ concentrations in the average input to the Columbia along this stretch of the river, and it would have to be a fairly uniform input with distance, since site-to-site differences are consistent.

A third possibility is that suspended sediment provides an exchangeable $\mathrm{U}$ reservoir for dissolved $\mathrm{U}$ in the river. Assuming $0.6 \mu \mathrm{g} / \mathrm{g}(\mathrm{ppm})$ exchangeable $\mathrm{U}$ associated with suspended particulates (Davis et al. 2004, value for the $<63$ micron fraction of Naturita sediment), a mass fraction of suspended sediment of $8.7 \times 10^{-5} \mathrm{~g} \mathrm{sed} / \mathrm{g} \mathrm{H}_{2} \mathrm{O}$ (Johnson et al. 2005 , including a sedimentation rate of $\sim 1 \mathrm{~cm} /$ year), and $0.5 \mu \mathrm{g} / \mathrm{L}$ of dissolved $\mathrm{U}$, suggests an exchangeable pool that is $\sim 10 \%$ of the total dissolved $U$. This is not sufficient to explain the $62 \%$ drop in ${ }^{236} \mathrm{U} /{ }^{238} \mathrm{U}$ seen between Sharp's Corner and Rooster Rock samples collected 10/14/04. Also a simple exchange mechanism would not explain the drop in $\mathrm{U}$ concentration down river (associated with the drop in the ${ }^{238} \mathrm{U}$ discharge rate). 
The simplest explanation is that the 300 Area source term is not constant and that the downriver decrease in ${ }^{236} \mathrm{U} /{ }^{238} \mathrm{U}$ (actually an increase with time) represent a damped response to an increase in the average 300 Area $U$ discharge rate with time during the several weeks leading up to the sampling events on 10/14/04. The downriver decline in ${ }^{236} \mathrm{U}$ discharge rate is accompanied by a decline in ${ }^{238} \mathrm{U}$ rate as well, but by only $32 \%$ compared to $75 \%$ for ${ }^{236} U$. Again, this would reflect an increasing ${ }^{238} U$ (or $U$ ) discharge rate, but at faster pace than for ${ }^{236} \mathrm{U}$. This would be consistent with an increased discharge rate of $\mathrm{U}$ with ${ }^{236} \mathrm{U}{ }^{238} \mathrm{U}<2 \times 10^{-8}$ to other portions, besides the 300 Area, of the Columbia River between the Priest Rapids Dam and Richland. A dynamic river-stage process that controls discharge of 300 Area $U$ to the Columbia River, should also drive the discharge in a similar sense (positively correlated in some fashion) from the uncontaminated portions of the aquifer between the Priest Rapids Dam and Richland. Though the $U$ concentration of the uncontaminated aquifer is at least about $3 \mathrm{ppb}$, the length of the Hanford Reach ( $\sim 80 \mathrm{~km} \mathrm{x2}$ to account for both banks) compared to the length $(<2 \mathrm{~km})$ of the 300 Area shore would tend to compensate for this.

\section{Bomb Fallout as a source of ${ }^{236} \mathrm{U}$ to the Columbia River}

Atmospheric testing of nuclear weapons by the U.S. and other countries from the first atomic bomb test in 1945 through the signing of the test ban treaty in 1963 (though France continued atmospheric testing until 1974, and China until 1980) spread bomb fallout including ${ }^{236} \mathrm{U}$ and other $\mathrm{U}$ isotopes world wide with variable deposition depending on atmospheric conditions. Thus there is a likely potential for fallout ${ }^{236} \mathrm{U}$ (along with bomb associated ${ }^{235} \mathrm{U}$ and ${ }^{238} \mathrm{U}$ ) to be mobilized with time to river systems of the Pacific Northwest including the Columbia. The data presented in this paper (Table S1) provides several constraints on the relative importance of such a contribution compared to U inputs from the Hanford 300 Area. The first constraint comes from the analyses of background river samples not likely to be affected by Hanford 300 Area U contributions. These include samples from the Columbia River at the Vernita Bridge (below Priest Rapids Dam, but up-river from Hanford operations), the Yakima River, the Snake River, two irrigation return canals, and (possibly) Columbia River samples from the east side of the river. All these samples have ${ }^{236} \mathrm{U} /{ }^{238} \mathrm{U}<2 \times 10^{-8}$ (Table S1), and by 
averaging (using Isoplot) the actual measured values weighted by their uncertainties (Table S1) results in a value of $7.8( \pm 4.82 \mathrm{~s}) \times 10^{-9}$ which may represent the contribution of fallout ${ }^{236} \mathrm{U}$. Using this value, along with water discharge rates and $U$ concentrations, the discharge rate of fallout ${ }^{236} \mathrm{U}$ from the above sources can be calculated. The value calculated based on the Vernita Bridge samples is $2.8 \times 10^{-11}$ moles fallout ${ }^{236} \mathrm{U}$ per second, which is more than two orders of magnitude smaller than the ${ }^{236} \mathrm{U}$ discharge rate $\left(5.68 \times 10^{-9}\right.$ moles $\left.{ }^{236} \mathrm{U} / \mathrm{sec}\right)$ based on the Sharp's Corner sample collected below McNary Dam. Totaling the fallout ${ }^{236} \mathrm{U}$ contributions from the Yakima River, Snake River, irrigation return canals, and up-river Columbia gives a value of $1.2 \times 10^{-10}$ moles fallout ${ }^{236} \mathrm{U} / \mathrm{sec}, 2 \%$ of the Sharp's Corner value $\left(5.68 \times 10^{-9}\right.$ moles $\left.{ }^{236} \mathrm{U} / \mathrm{sec}\right)$.

A second constraint comes from Figure 6 in the main paper that plots ${ }^{236} \mathrm{U} /{ }^{238} \mathrm{U}$ vs. ${ }^{235} \mathrm{U} /{ }^{238} \mathrm{U}$ for the samples collected in the lower Columbia. The lower Columbia samples plot within error to the best fit line to the data for the fall 2003300 Area and RPH traverses, suggesting that they share a common 300 Area source (see Figure 5). Though the lower Columbia samples overlap at the 2s level shown (Figure 6), they do appear to be shifted slightly to the right relative to the fall 2003 best-fit line. This may be due to addition of fallout $\mathrm{U}$, unfortunately there is no published study (at least that the authors have found) involving fallout $U$ where both ${ }^{236} U /{ }^{238} U$ and ${ }^{235} U /{ }^{238} U$ were measured and characterized for fallout. However, comparing results from Sakaguchi et al. (2009) for ${ }^{236} \mathrm{U} /{ }^{238} \mathrm{U}$ with results from Warneke et al. (2002) for ${ }^{235} \mathrm{U} /{ }^{238} \mathrm{U}$ suggests that fallout ${ }^{236} \mathrm{U}$ would be accompanied by $\mathrm{U}$ with ${ }^{235} \mathrm{U} /{ }^{238} \mathrm{U}$ of 0.007469 to 0.007766 . Using those values, along with the ${ }^{235} \mathrm{U} /{ }^{238} \mathrm{U}$ for the Sharp's Corner sample (range used is the measured value plus 2 s error) suggests that at most the contribution of fallout to the measured ${ }^{236} \mathrm{U} /{ }^{238} \mathrm{U}$ would be 0.6 to $2.5 \%$, similar to the estimate in the paragraph above. If fallout ${ }^{236} \mathrm{U}$ is accompanied by even higher ${ }^{235} \mathrm{U} /{ }^{238} \mathrm{U}$, then this limit would be lower.

Finally the third constraint is based on the downriver variation in ${ }^{236} \mathrm{U}$ discharge rate (and ${ }^{236} U /{ }^{238} U$ ) represented by the Columbia samples collected Oct. 14, 2004. If fallout ${ }^{236} \mathrm{U}$ were added in significant amounts, then it would be expected that with successive samples downriver an increase in ${ }^{236} \mathrm{U}$ discharge rate would be observed. Table S2 compiles the ${ }^{236} U$ rates for the Columbia River samples collected at Sharp's Corner, Celilo Village and Rooster Rock on 10/14/04. The discharge rate of ${ }^{236} \mathrm{U}$ decreases 
downriver by 32\% between Sharp's Corner (below McNary Dam) and Rooster Rock (below Bonneville Dam), contrary to expectation if tributary contributions of ${ }^{236} \mathrm{U}$ to that reach of the Columbia were significant.

\section{References}

Buchholz, B. A.; Brown, T. A.; Hamilton, T. F.; Hucheon, I. D.; Machetti, A. A.; Martinelli, R. E.; Ramon, E. C.; Tumey, S. J.; and Williams, R.W. (2007) Investigating uranium isotopic distributions in environmental samples using AMS and MC-ICPMS. Nucl. Instrum. Methods Phys. Res. B, 2007, 259, 733-738.

Boulyga, S. F.; Klötzli, U.; and Prohaska, T. (2006) Improved abundance sensitivity in MC-ICP-MS isotope ratios in the $10^{-7}$ to $10^{-8}$ range. J. Anal. Atom. Spec. 2006, 21, 1427 1430.

Christensen, J. N.; Dresel, P. E.; Conrad, M. E., Maher, K. and DePaolo, D. J. Identifying the sources of subsurface contamination at the Hanford Site in Washington using highprecision uranium isotopic measurements. Environ. Sci. Technol. 2004, 38, 3330-3337.

Christensen, J. N., Conrad, M. E., DePaolo, D. J., Dresel, P. E. Isotopic studies of contaminant transport at the Hanford Site, Washington. Vadose Zone J., 2007, 6, 10181030 .

Davis, J. A.; Meece, D. E.; Kohler, M.; Curtis, P. Approaches to surface complexation modeling of Uranium(VI) adsorption on aquifer sediments. Geochim. Comsmochim. Acta 2004, 68, 3621-3641.

Friedlander, G.; Kennedy, J. W.; Macias, E. S.; Miller, J. M. Nuclear and Radiochemistry, $3^{\text {rd }}$ ed., John Wiley and Sons: New York, 1981.

Johnson, V. G.; Peterson, R.E.; Olsen, K. B. Heavy metal transport and behavior in the lower Columbia River, USA. Eviron. Monit. Assess. 2005, 110, 271-289.

Luo, X. Z.; Rehkämper, M.; Lee, D.-C., Halliday, A. N. High precision Th-230/Th-232 and U-234/U-238 measurements using energy-filtered ICP magnetic sector multiple collector mass spectrometry. Int. J. Mass Spectrom. Ion Processes 1997, 171, 105-117.

Sakaguchi, A.; Kawai, K.; Steier, P.; Quinto, F.; Mino, K.; Tomita, J.; and Hoshi, M.; Whitehead, N.; Yamamoto, M. First results on ${ }^{236} \mathrm{U}$ levels in global fallout. Science Total Environment 2009, 407, 4238-4242. 
Steier, P.; Bichler, M.; Fifield, L. K.; Gosler, R.; Kutschera, W.; Priller, A.; Quinto, F.; Richter, S.; Srncik, M.; Terrasi, P.; Wacker, L.; Wallner, A.; Wallner, G.; Wilcken, K. M.; Wild, E. M. Natural and anthropogenic 236U in environmental samples. Nuclear Instruments and Methods in Physics Research B 2008, 266, 2246-2250.

Warneke, T.; Croudace, W.; Warwick, P. E.; Taylor, R. N. A new ground-level fallout record of uranium and plutonium isotopes for northern temperate latitudes. Earth Planet. Sci. Lttrs. 2002, 203, 1047-1057.

United States Army Corps of Engineers, Northwestern Division, McNary Dam http://www.nwd-wc.usace.army.mil/perl/dataquery.pl?k=mcnary click on "Outflow Discharge (KCFS)"

United States Geological Survey, Instantaneous Data Archive for the Columbia River below Priest Rapids Dam, WA

http://ida.water.usgs.gov/ida/available_records.cfm?sn=12472800

USGS National Stream Quality Accounting Network (NASQAN)

http://nwis.waterdata.usgs.gov/or/nwis/qwdata 

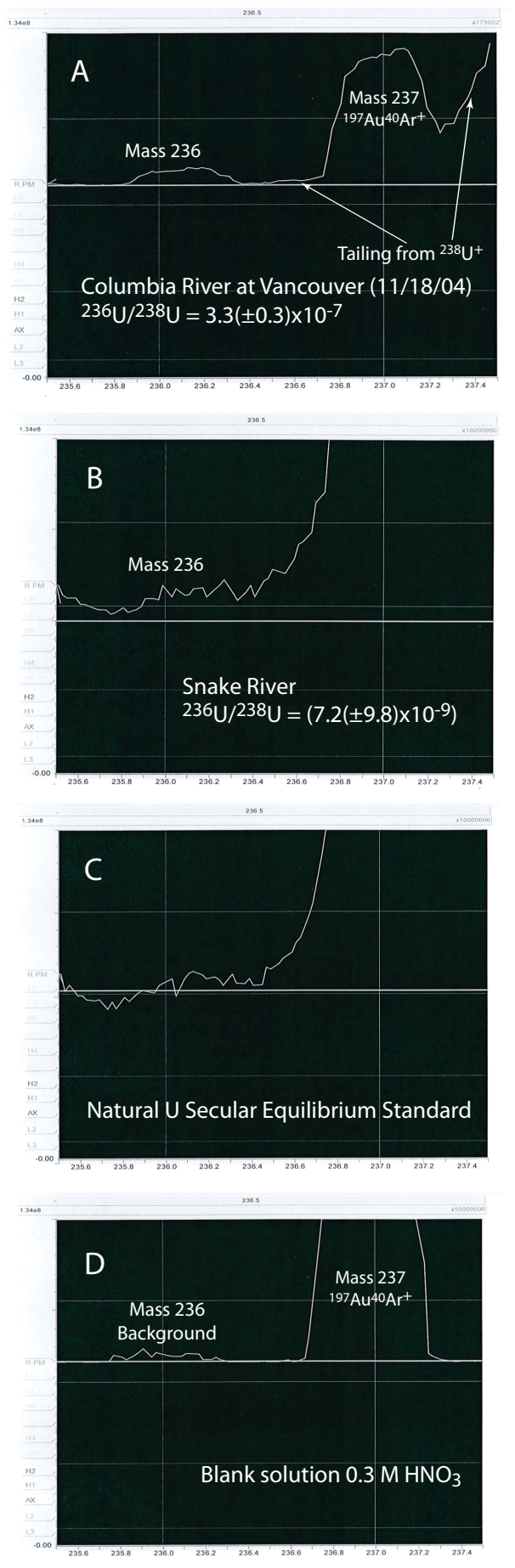

Figure S1. Mass scans taken during the analysis session for the (A) Vancouver, WA and (B) Snake River samples, but are not representative of the conditions during the analysis of all the other samples presented in Table S1 when abundance sensitivity was $\sim 8$ times better due to better flight tube pressure. Also shown are mass scans for the natural $\mathrm{U}$ secular equilibrium standard (C), and a blank solution (D). 

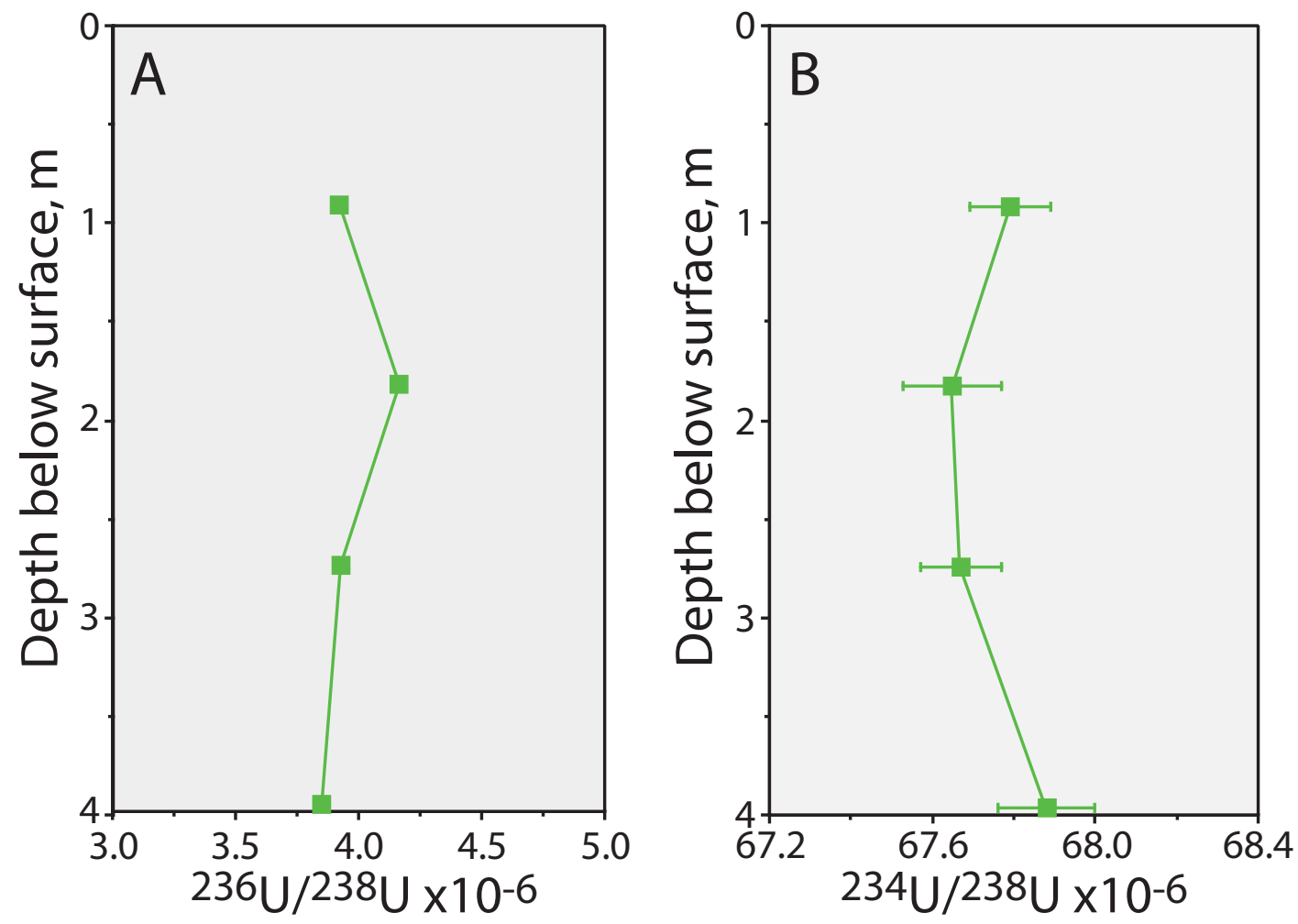

Figure S2. Depth profile sampled 3/30/04 for the Richland Pump House $100 \mathrm{~m}$ off the west bank of the Columbia River. (A) ${ }^{236} U /{ }^{238} U \times 10^{-6}$ (B) ${ }^{234} \mathrm{U} /{ }^{238} \mathrm{U} \times 10^{-6}$. Depth of the river at this point of the traverse was $\sim 4 \mathrm{~m}$. 


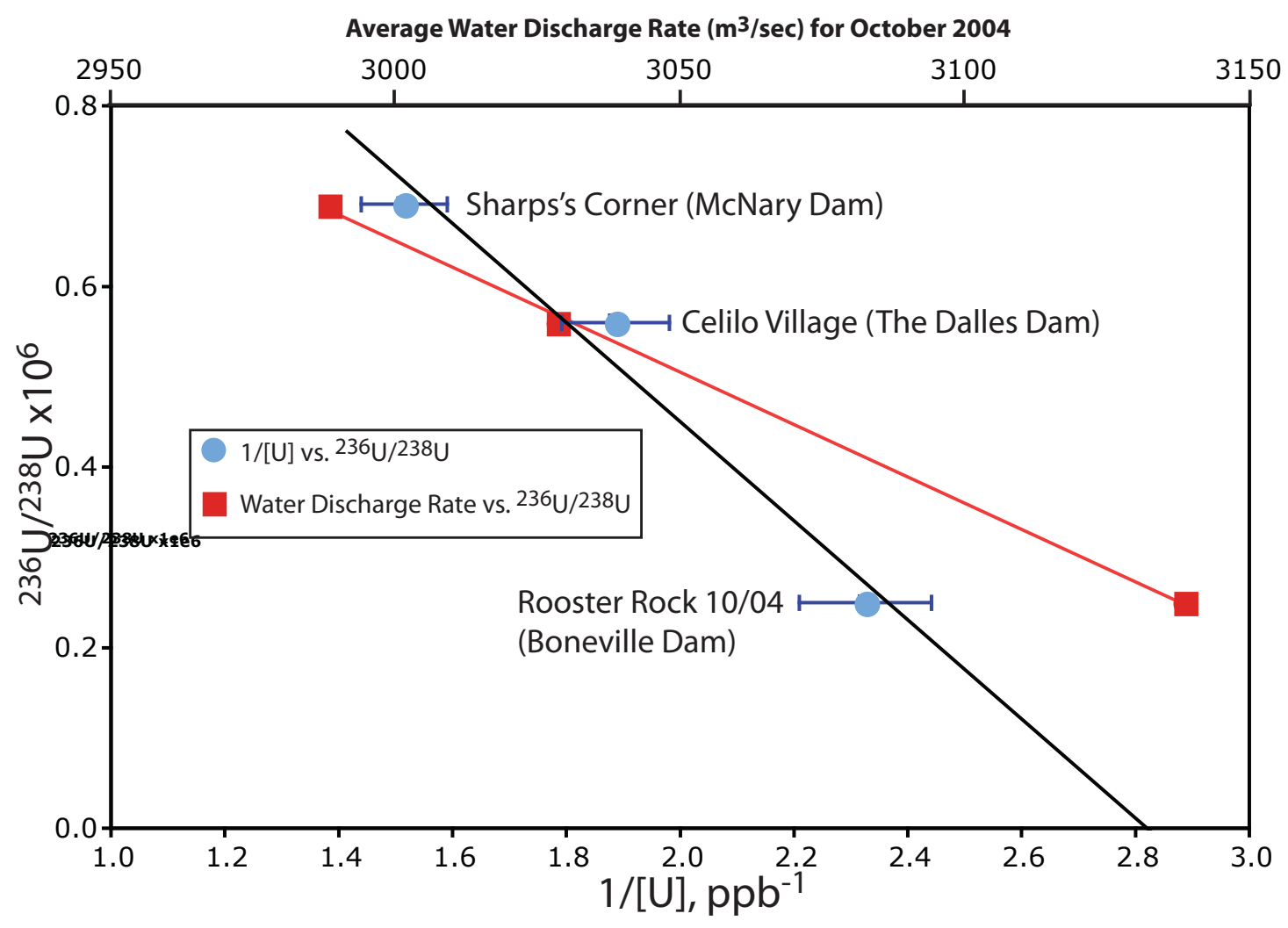

Figure S3. Plot of ${ }^{236} \mathrm{U} /{ }^{238} \mathrm{U} \times 10^{6}$ against the inverse of the uranium concentration $(1 /[\mathrm{U}], \mathrm{L} / \mu \mathrm{g}))($ blues circles) compared to a plot of the average water discharge rate for Oct. 2004 (red squares) for samples downriver of McNary Dam taken on Oct. 14, 2004. 


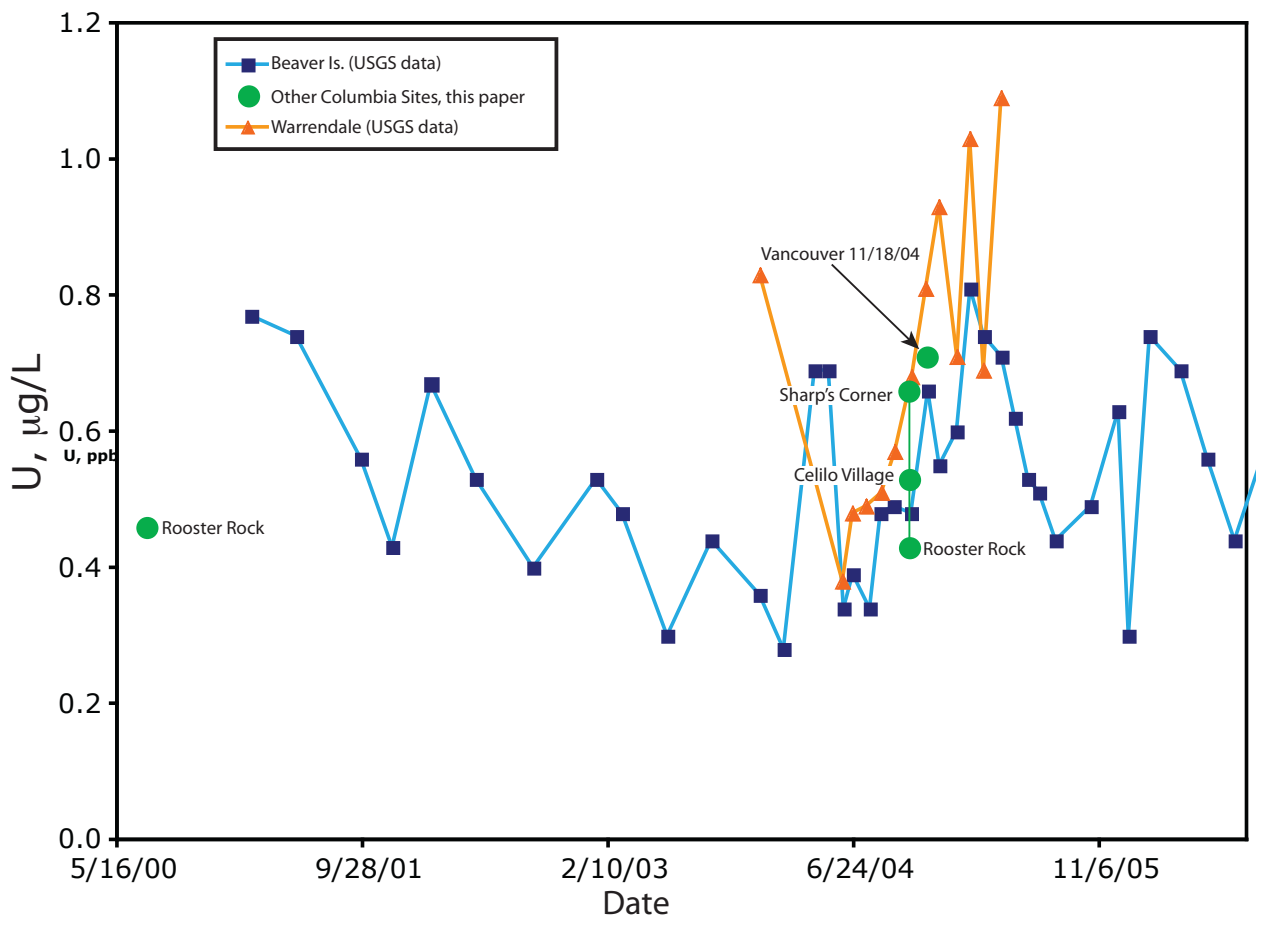

Figure S4. Time series of $U$ concentration of filtered Columbia River samples. Shown are USGS data for samples collected at Beaver Is. (see Figure 3) and Warrendale, and U concentrations for filtered Columbia River samples from this paper (Table S1). USGS data obtained online from: http://nwis.waterdata.usgs.gov/or/nwis/qwdata 


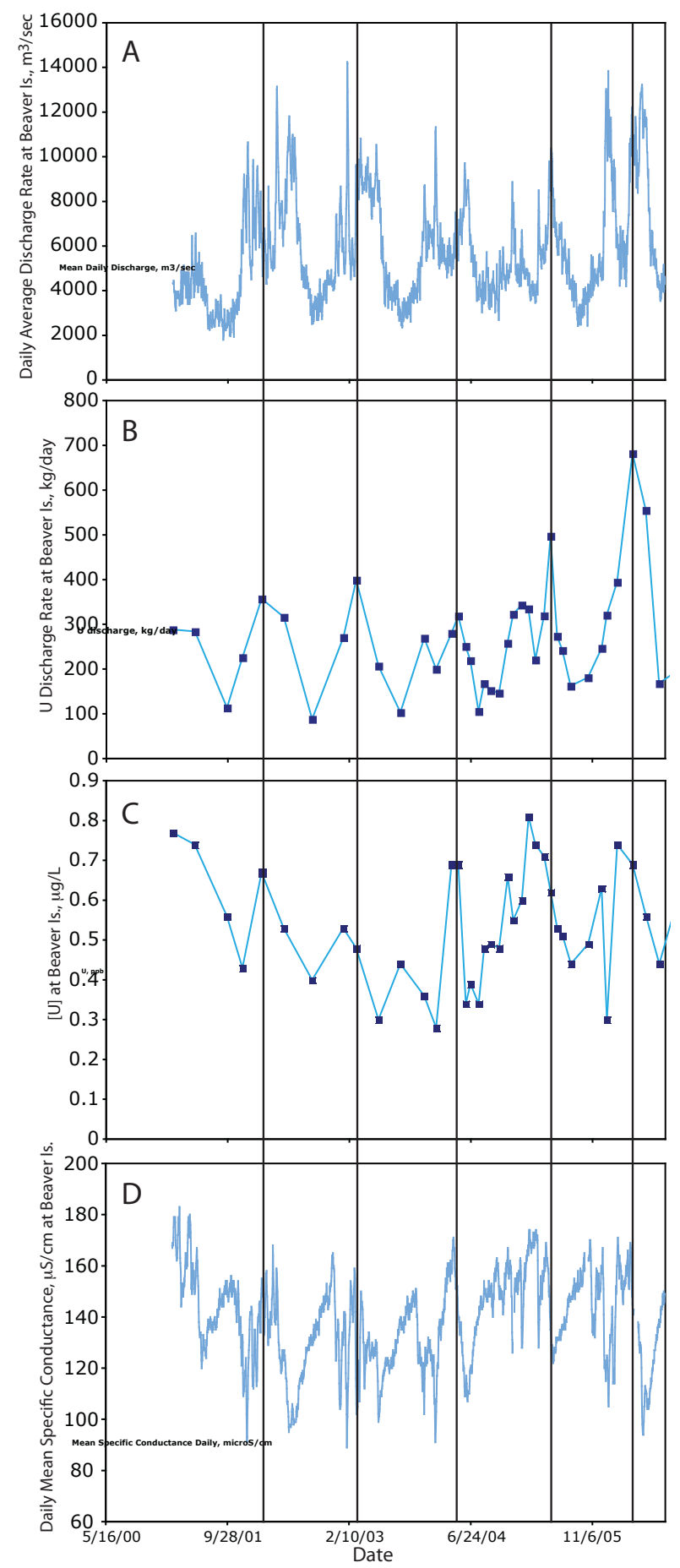

Figure S5. Comparison between time series of (A) the daily average discharge of the Columbia R. measured at Beaver Is., (B) the calculated U discharge rate at Beaver Is., (C) the U concentration ( $\mu \mathrm{g} / \mathrm{L})$. Data from the USGS, obtained online from: http://nwis.waterdata.usgs.gov/or/nwis/qwdata 


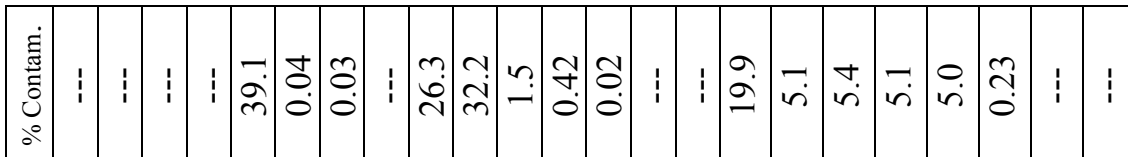

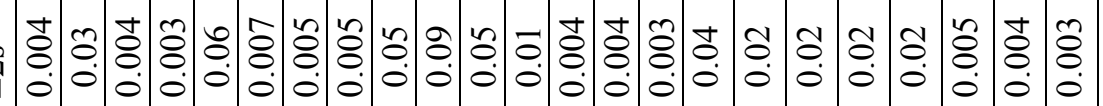

$\dot{\dot{s}} \stackrel{\stackrel{0}{x}}{\stackrel{x}{x}}$

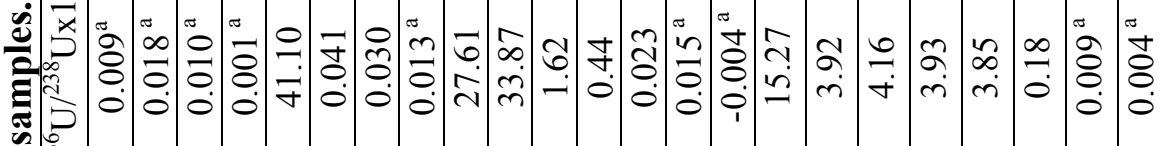
कू⿻ 丨

先

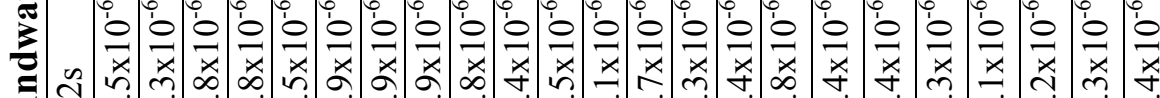
\# ta $\infty$ N

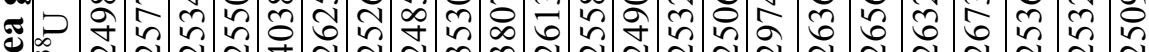

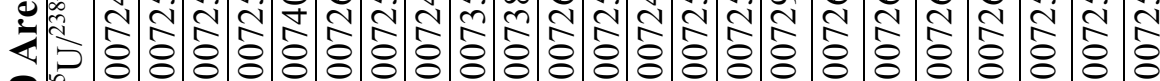
品

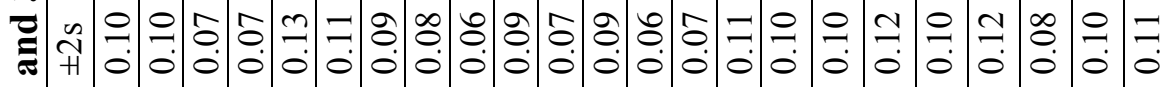

ฺั

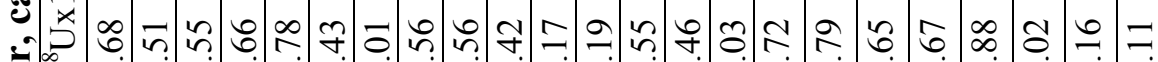
或

를

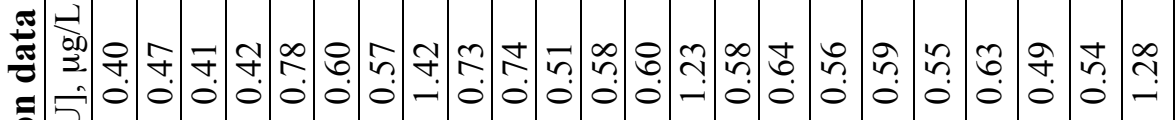

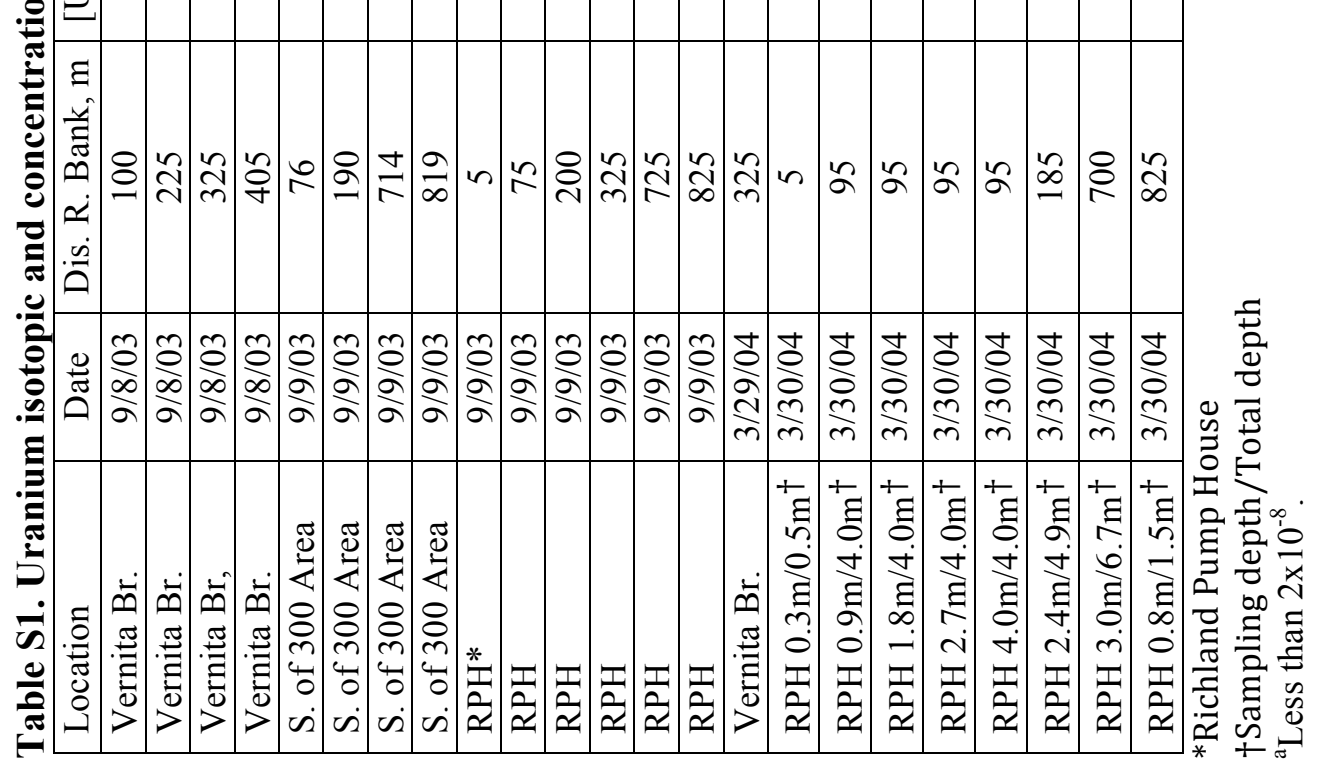




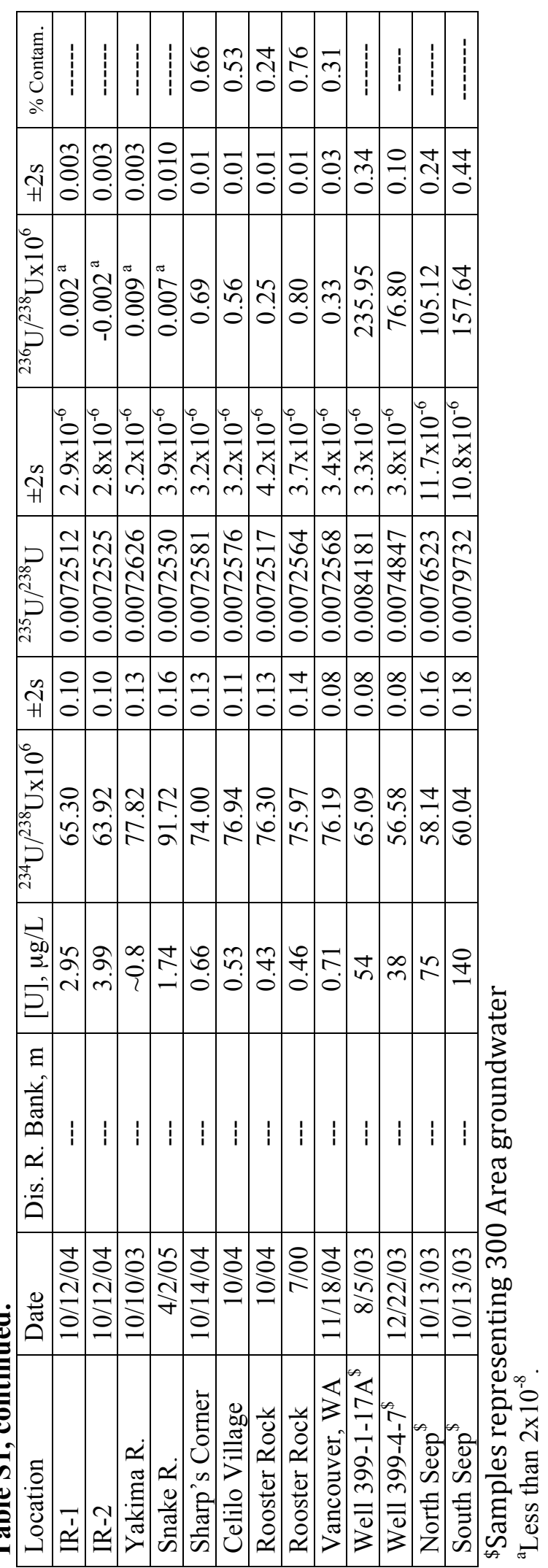



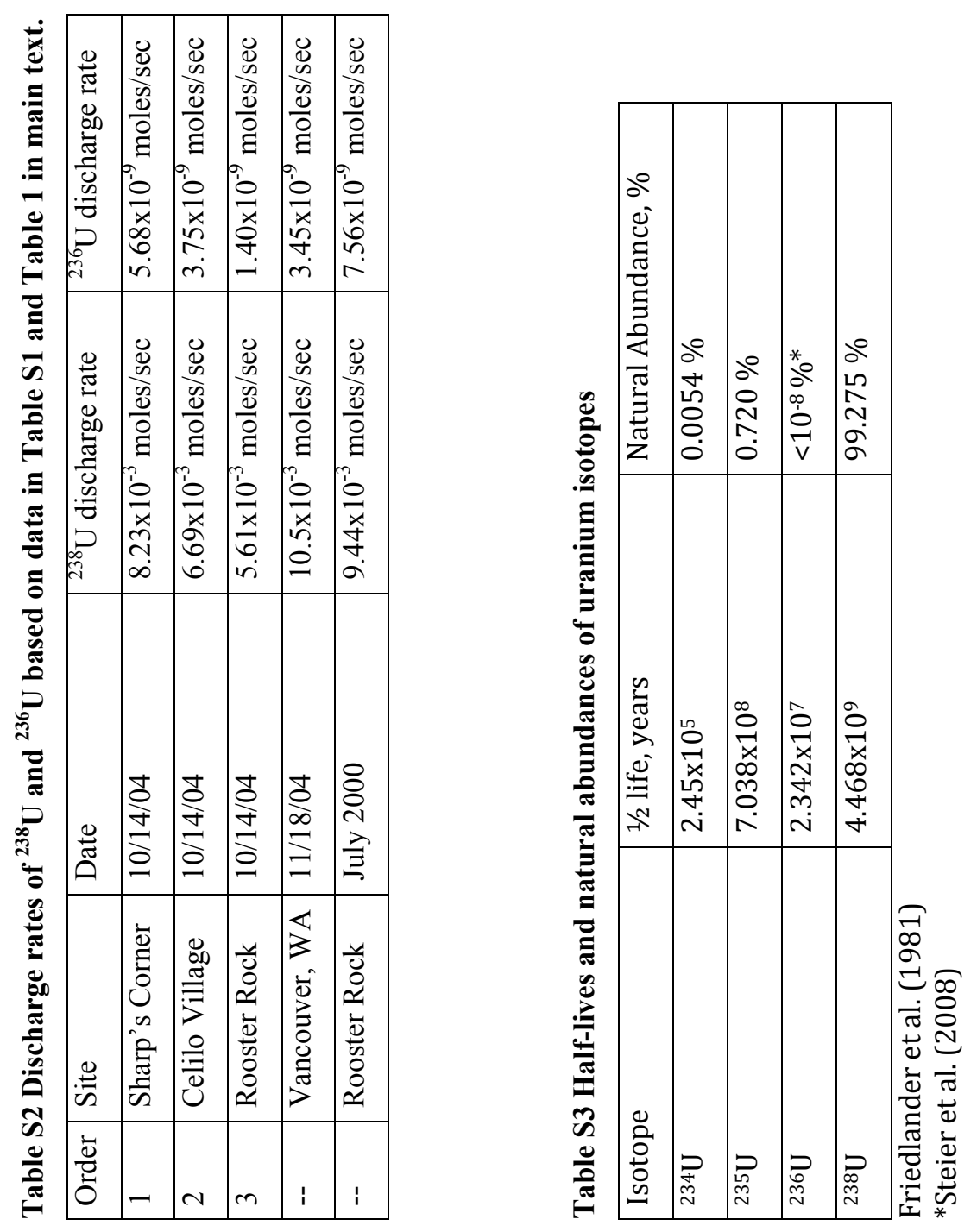


\section{DISCLAIMER}

This document was prepared as an account of work sponsored by the United States Government. While this document is believed to contain correct information, neither the United States Government nor any agency thereof, nor the Regents of the University of California, nor any of their employees, makes any warranty, express or implied, or assumes any legal responsibility for the accuracy, completeness, or usefulness of any information, apparatus, product, or process disclosed, or represents that its use would not infringe privately owned rights. Reference herein to any specific commercial product, process, or service by its trade name, trademark, manufacturer, or otherwise, does not necessarily constitute or imply its endorsement, recommendation, or favoring by the United States Government or any agency thereof, or the Regents of the University of California. The views and opinions of authors expressed herein do not necessarily state or reflect those of the United States Government or any agency thereof or the Regents of the University of California. 